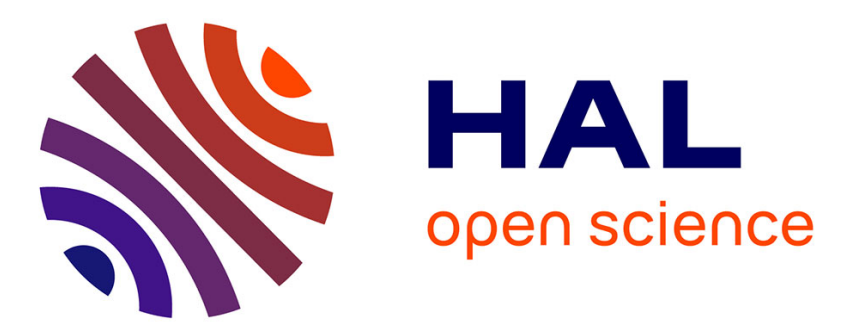

\title{
Superposed parageneses in the spurrite-, tilleyite and gehlenite-bearing skarns from Cornet Hill, Apuseni mountains, Romania
}

Stefan Marincea, Essaïd Bilal, Jean Verkaeren, Marie-Lola Pascal, Michel Fonteilles

\section{To cite this version:}

Stefan Marincea, Essaïd Bilal, Jean Verkaeren, Marie-Lola Pascal, Michel Fonteilles. Superposed parageneses in the spurrite-, tilleyite and gehlenite-bearing skarns from Cornet Hill, Apuseni mountains, Romania. The Canadian Mineralogist, 2001, 39 (5), pp.1435-1453. 10.2113/gscanmin.39.5.1435 . emse-00613199

\section{HAL Id: emse-00613199 \\ https://hal-emse.ccsd.cnrs.fr/emse-00613199}

Submitted on 11 Jun 2020

HAL is a multi-disciplinary open access archive for the deposit and dissemination of scientific research documents, whether they are published or not. The documents may come from teaching and research institutions in France or abroad, or from public or private research centers.
L'archive ouverte pluridisciplinaire HAL, est destinée au dépôt et à la diffusion de documents scientifiques de niveau recherche, publiés ou non, émanant des établissements d'enseignement et de recherche français ou étrangers, des laboratoires publics ou privés. 


\title{
SUPERPOSED PARAGENESES IN THE SPURRITE-, TILLEYITE- AND GEHLENITE-BEARING SKARNS FROM CORNET HILL, APUSENI MOUNTAINS, ROMANIA
}

\author{
ŞTEFAN MARINCEA ${ }^{\S}$ AND ESSAÏD BILAL \\ Centre SPIN, Ecole Nationale Supérieure des Mines de Saint-Etienne, 158, Cours Fauriel, \\ F-42023 Saint-Etienne Cedex 2, France
}

JEAN VERKAEREN

Unité de Géologie, Université Catholique de Louvain, 3, place Louis Pasteur, B-1348 Louvain-la-Neuve, Belgium

MARIE-LOLA PASCAL

CNRS-ISTO (Institut des Sciences de la Terre d'Orléans), 1A, rue de la Férollerie, F-45071 Orléans Cedex 2, France

\section{MICHEL FONTEILLES}

CNRS - Laboratoire de Pétrologie, Université Pierre-et-Marie-Curie, 4, place Jussieu, F-75252 Paris Cedex 5, France

\begin{abstract}
We describe the occurrence of high-temperature, spurrite-, tilleyite- and gehlenite-bearing skarns from Cornet Hill, part of the Metaliferi Massif, Apuseni Mountains, Romania, and the main mineral species developed in these rocks. The host skarns are developed at the contact between a quartz monzonitic - monzodioritic body of Paleocene - Ypresian age and Tithonian limestones. The primary mineral assemblage mainly consists of tilleyite, spurrite and gehlenite, with various amounts of garnet and wollastonite; perovskite, monticellite and hydroxylellestadite are present but scarce. The skarns have clearly undergone a late metasomatic event, which produced, for example, diopside veins cross-cutting tilleyite, spurrite, and gehlenite, and small masses and veins of vesuvianite replacing gehlenite. Subsequent hydrothermal and weathering overprints on the primary assemblages resulted in the formation of three secondary parageneses: (1) an early hydrothermal one that includes scawtite, xonotlite and hibschite, (2) a late hydrothermal one that includes 11 A tobermorite, riversideite, thomsonite, gismondine, aragonite, and calcite, and (3) a weathering paragenesis that includes plombièrite, portlandite, and allophane. The main properties of these mineral species, as revealed using chemical, optical and X-ray powder analyses, are reported here. We document the first occurrence of plombièrite, tobermorite, riversideite, portlandite and allophane in Romania.
\end{abstract}

Keywords: high-temperature calcic skarns, superposed parageneses, mineral data, gehlenite, spurrite, tilleyite, hibschite, scawtite, xonotlite, tobermorite, riversideite, plombièrite, Cornet Hill, Romania.

\section{SOMMAIRE}

Dans cet article, nous décrivons des skarns calciques de très haute température, à spurrite, tilleyite et géhlénite de la Colline de Cornet, partie du Massif de Metaliferi, Monts Apuseni, en Roumanie, et les plus importantes espèces minérales de ces roches. Les skarns hôtes sont développés au contact d'un corps monzonitique quartzifère à monzodioritique d'âge Paléocène - Yprésien avec des calcaires d'âge tithonien. L'assemblage minéralogique primaire est essentiellement composé de tilleyite, spurrite et géhlénite, auxquels s'ajoutent en teneurs variées du grenat et de la wollastonite et, plus rarement, pérovskite, monticellite et hydroxylellestadite. Les skarns ont clairement subi un deuxième événement métasomatique qui a conduit, par exemple, au développement de veines de diopside recoupant la tilleyite, la spurrite ou la géhlénite, et de plages et de veines de vésuvianite remplaçant la géhlénite. L'empreinte laissée par l'altération hydrothermale et météorique des paragenèses primaires se traduit par la formation de trois paragenèses secondaires: (1) une paragenèse hydrothermale précoce, qui comprend scawtite, xonotlite et hibschite, (2) une paragenèse hydrothermale tardive, comprenant tobermorite-11 Å, riversideïte, thomsonite, gismondine, arago-

$\S \quad$ Present address: Geological Institute of Romania, 1 Caransebes Street, RO-78344 Bucharest, Romania. E-mail address: marincea@igr.ro 
nite et calcite, et (3) une paragenèse d'altération supergène qui a donné naissance à plombièrite, portlandite et allophane. Nous présentons les principaux paramètres tirés des études chimiques, optiques et par diffraction des rayons $\mathrm{X}$ en poudres de ces espèces minérales. Nous donnons les premières descriptions de plombièrite, tobermorite, riversideïte, portlandite et allophane sur le territoire de la Roumanie.

Mots-clés: skarns calciques de haute température, paragenèses superposées, données minéralogiques, géhlénite, spurrite, tilleyite, hibschite, scawtite, xonotlite, tobermorite, riversideïte, plombièrite, Colline de Cornet, Roumanie.

\section{INTRODUCTION}

The occurrences of high-temperature calcic skarns are relatively rare. Worldwide, various authors have reported over thirty examples of such rocks ( $c f$. Reverdatto 1970, Piret 1997). The occurrence of spurrite-, tilleyite- and gehlenite-bearing skarns in the Cornet Hill area, associated with the Upper Cretaceous to Paleocene magmatism in the Metaliferi Massif, Apuseni Mountains of Romania, has been known for over two decades (Istrate et al. 1978). Two other occurrences of high-temperature skarn have also been described in Romania, at Mâgureaua Vaţei (Ştefan et al. 1978) and Oravita (Constantinescu et al. 1988). In the skarn from Cornet Hill, Istrate et al. (1978) revealed the presence of additional high-temperature phases such as wollastonite, vesuvianite, calcic garnets and spinel. In two recent studies, Piret et al. $(1997,1998)$ contributed new information on the main high-temperature minerals and mentioned the presence of scawtite. Pascal et al. (2001) summarize the main textural features and mineral relationships within the high-temperature assemblages at Cornet Hill, and mention the presence of hydroxylellestadite, monticellite, perovskite and xonotlite.

The appearance and parageneses of the Cornet Hill skarn closely match those reported by Burnham (1959) at Crestmore (California), by Agrell (1965) at Kilchoan (Scotland), by Sabine \& Young (1975) at Carneal (Northern Ireland), and by Henmi et al. (1977) at Fuka, Mihara and Kushiro (Japan). On the basis of these investigations, retrograde parageneses can be expected to be superposed on the primary associations. There remains a paucity of data about the composition, optics and crystallographic parameters of these minerals; our aim here is to offer a brief description of the mineral species in the superposed parageneses from Cornet Hill.

\section{Geological Setting}

The Cornet Hill area is located approximately $20 \mathrm{~km}$ west of Brad, and $40 \mathrm{~km}$ northwest of Deva. The spurrite-, tilleyite- and gehlenite-bearing skarns occur at the contact of a monzodiorite - quartz monzonite body, of probable Paleocene - Ypresian age (Ştefan $e t$ al. 1988). This magmatic body was certainly emplaced during the "banatitic" event, of Upper Cretaceous Paleogene age, and may be described as consisting of "banatite", a term coined by von Cotta (1864). The skarns outcrop to the north of the intrusive body, over an area of several hundreds of square meters. Their protolith consists of micritic reef limestones with clastic interlayers and is probably of Tithonian age. A geological sketch of the Cornet Hill area, as well as its location, is given in Figure 1.

The systematic distribution of various minerals across the skarn area suggests the presence of metasomatic zoning. From the outer to the inner part of the metasomatized contact, the zoning described by Istrate et al (1978) consists of calcite (marble) / tilleyite / spurrite / wollastonite + gehlenite + vesuvianite / quartz monzonite. Pascal et al. (2001) describe this zoning in greater detail, and distinguish an endoskarn wollastonite - grossular zone at the contact of the intrusive body. For simplicity in the general location of the samples, this work refers to the original zoning proposed by Istrate et al. (1978), with mostly tilleyite-, spurrite- and (gehlenite + wollastonite)-bearing zones, hereafter referred to as $\mathrm{CH} 3, \mathrm{CH} 2$ and $\mathrm{CH} 1$.

Late assemblages of secondary minerals form fracture-filling, generally very fine-grained and locally porous aggregates within the primary calcium silicates. The alteration textures, of quite limited extent, occur mainly in the $\mathrm{CH} 3$ zone, which consists of a very coarse-grained tilleyite skarn.

\section{Analytical Methods}

Electron-microprobe analyses (EMPA) were performed using two different CAMECA SX-50 instruments, at an accelerating voltage of $15 \mathrm{kV}$ and a beam current of $10 \mathrm{nA}$, with a beam diameter of 5 to $10 \mu \mathrm{m}$. Both electron microprobes rely on wavelength-dispersion spectrometry. The slightly defocused spot of $10 \mu \mathrm{m}$ was used to prevent burn-up of the carbonate-bearing and hydrous minerals and to diminish the risk of volatilization of sodium. Natural diopside ( $\mathrm{Si}, \mathrm{Mg}$ and $\mathrm{Ca} K \alpha)$, synthetic hematite $(\mathrm{Fe} K \alpha)$, natural orthoclase (K and $\mathrm{Al} K \alpha)$, natural albite $(\mathrm{Na} K \alpha)$, natural pyrophanite

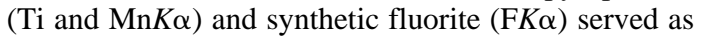
standards. Counting time was $20 \mathrm{~s}$ per element. Data were reduced and corrected using the PAP procedure (Pouchou \& Pichoir 1985). In the case of very fine, fibrous minerals (e.g., tobermorite, plombièrite, riversideite, xonotlite), we were unable to determine the composition of individual crystals, because the particle size was much smaller than the excited volumes. Consequently, the compositions given for these mineral species pertains to bunches of crystals, which were 

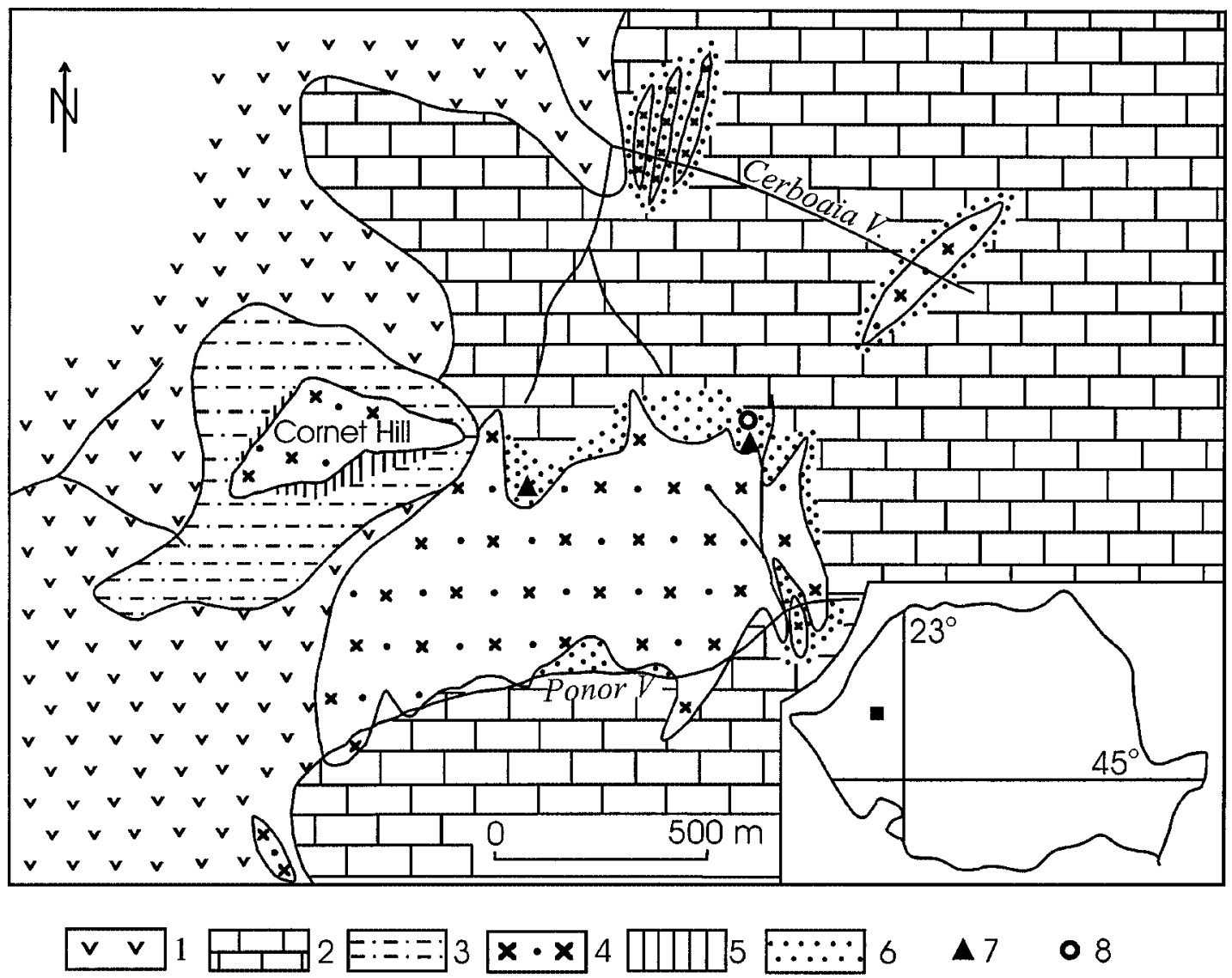

FIG. 1. Geological sketch of the Cornet Hill area (redrawn from Istrate et al. 1998). Symbols in the legend represent: 1 Mesozoic ophiolites, 2 Tithonian limestones, 3 Cretaceous sedimentary deposits (marls, calcareous sandstones and clays), 4 quartz monzodiorite, 5 hornfels, 6 skarns, 7 occurrence of spurrite, 8 occurrence of tilleyite.

analyzed only after detailed checks for chemical homogeneity using back-scattered electron imagery. In tilleyite, spurrite and scawtite, the carbon content was calculated assuming stoichiometry. The calculated $\mathrm{C}$ values are as a result sensitive to the measured $\mathrm{Si}$ content. For this reason, the same samples of silicate-carbonates were analyzed with both probes. No detectable difference in the analytical results using the two instruments was found, particularly for $\mathrm{SiO}_{2}$ and $\mathrm{CaO}$, and even for elements close to the lower limits of detection (e.g., in the case of $\mathrm{Mn}, \mathrm{Mg}$ and $\mathrm{Fe}$ ); consequently, the results of the analyses are considered to be very reliable, and no major errors were introduced by the method of calculation of $\mathrm{CO}_{2}$. The usual problems occurred in the analysis of the carbonate-bearing and hydrous minerals (e.g., scawtite, plombièrite, xonotlite, tobermorite, riversideite), owing to the high totals after recalculation of carbonate or $\mathrm{H}_{2} \mathrm{O}$. In spite of this problem, these minerals apparently have good stoichiometry, which also indicates the reliability of the analyses.

Freshly exposed surfaces of many secondary phases were observed using a JEOL JSM-840 scanning electron microscope set at $15 \mathrm{kV}$ acceleration voltage and $10 \mathrm{nA}$ beam current.

Parallel records of thermogravimetric (TGA), differential thermogravimetric (DTG) and differential scanning calorimetric (DSC) curves of some separates were done using a SETARAM TAG 24 thermobalance coupled with a DSC 111 thermal analyzer; we applied a heating rate of $10^{\circ} \mathrm{C} / \mathrm{min}$, under a constant flow of nitrogen $(5 \mathrm{~mL} / \mathrm{min})$. In order to determine the nature of the gases liberated, the outlet of the gas stream was directed toward and analyzed using a FTS 40 (BIORAD) infrared spectrometer.

X-ray powder diffraction (XRD) analyses were performed using an automated Siemens D-5000 Kristallo- 
flex diffractometer. Graphite-monochromatized $\mathrm{Cu} K \alpha$ radiation $(\lambda=1.54056 \AA)$, a scan speed of $0.02^{\circ} 2 \theta$ per second, a time per step of $2 \mathrm{~s}$, an operating voltage of $40 \mathrm{kV}$ for a current of $30 \mathrm{~mA}$, and a slit system of 1/0.1/ 1 with a receiving slit of $0.6 \mathrm{~mm}$, were used for most of measurements. Annealed fluorite $[a=5.4638(3) \AA]$ was used as an internal standard. The full set of X-ray powder data is available from the first author upon request.

Unit-cell parameters were obtained by least-squares refinement of the primary data, using the computer program of Appleman \& Evans (1973), as revised for microcomputer use by Benoit (1987). In Table 1, we report the unit-cell data for the high-temperature minerals, whereas in Table 2, we list the cell parameters measured for the minerals resulted from the alteration of the primary parageneses.

The indices of refraction were determined using a conventional JENAPOL-U petrographic microscope with a spindle stage and calibrated immersion liquids (Cargille or temperature-calibrated oils), with a 589-nm interference filter.

\section{Mineralogical Data on the High-Temperature Minerals}

We propose only a brief investigation of the main high-temperature silicate phases, as we focus on the alteration phases. Pascal et al. (2001) provide more complete descriptions of some of the high-temperature phases, mainly from the $\mathrm{CH} 1$ zone. Further details on the mineralogy of the $\mathrm{CH} 2$ and $\mathrm{CH} 3$ zones, as well as chemical data for the high-temperature minerals, will be published later (Marincea et al., in prep.).

\section{Tilleyite}

At Cornet Hill, tilleyite is one of the most abundant silicate phases. It represents the main constituent of the outer zone of the high-temperature skarn (CH 3), which grades inward into the spurrite zone. In hand specimen, the mineral is bluish gray to dark gray and is cross-cut by a web-like network of thin (up to $3 \mathrm{~mm}$ ) white veinlets that segregates essentially monomineralic "orbicules" of tilleyite up to $5 \mathrm{~cm}^{2}$ in size. On microscopic examination, the vein system was found to contain scawtite, calcite, and some optically indeterminable "cryptocrystalline" phases, identified as calcite + plombièrite \pm tobermorite or riversideite by XRD.

The indices of refraction measured for a representative sample of tilleyite are: $\alpha$ 1.609(2), $\beta$ 1.631(2), $\gamma$ $1.652(3)$. The mineral is optically positive, with a $2 \mathrm{~V}$ (measured) of $87.5^{\circ}$, which perfectly matches with the calculated value $\left(2 V_{\text {calc }} 87.53^{\circ}\right)$. The unit-cell parameters of two representative samples are given in Table 1.

Electron-microprobe studies reveal little variation in the compositions of either tilleyite or spurrite within individual samples. No chemical zoning was observed within individual crystals. Chemical data for a representative set of samples were consequently averaged and are presented in Table 3 . The chemical compositions of individual samples represent average results of 3 to 15 single point-analyses within the same thin section. The

TABLE 1. CRYSTALLOGRAPHIC PARAMETERS OF SELECTED PRIMARY MINERALS IN THE CORNET HILL SKARNS

\begin{tabular}{|c|c|c|c|c|c|c|c|c|c|c|c|c|}
\hline Mineral & System & $\begin{array}{l}\text { Space } \\
\text { group }\end{array}$ & Sample & Zone & $a(\AA)$ & $b(\AA)$ & $c(\AA)$ & $\beta^{(0)}$ & $V\left(\AA^{3}\right)$ & $\underset{(1)}{\mathrm{n}}$ & $\begin{array}{l}\mathrm{N} \\
(2)\end{array}$ & $\begin{array}{l}2 \theta \text { range } \\
\left({ }^{\circ}\right)^{(3)}\end{array}$ \\
\hline tilleyite & $\mathbf{M}$ & $P 2_{1} / a$ & 2301 & CH 3 & $15.096(8)$ & $10.241(5)$ & $7.576(4)$ & $105.17(3)$ & $1130.4(7)$ & 5 & 87 & $10-60$ \\
\hline tilleyite & M & $P 2_{1} / a$ & 2315 & $\mathrm{CH} 3$ & $15.121(8)$ & $10.258(6)$ & $7.579(4)$ & $105.23(3)$ & $1134.3(8)$ & 4 & 85 & $10-60$ \\
\hline spurrite & M & $P 2_{1} / \mathrm{a}$ & P 49 & $\mathrm{CH} 2$ & $10.515(5)$ & $6.728(3)$ & $14.203(6)$ & $101.40(2)$ & $985.0(1)$ & 5 & 40 & $10-60$ \\
\hline spurrite & $\mathrm{M}$ & $P 2_{1} / a$ & 2160 & $\mathrm{CH} 2$ & $10.504(8)$ & $6.716(4)$ & $14.183(7)$ & $101.39(4)$ & $980.8(2)$ & 5 & 38 & $10-60$ \\
\hline gehlenite & $Q$ & $P \overline{4} 2_{1} m$ & 2160 & $\mathrm{CH} 2$ & $7.684(3)$ & - & $5.061(2)$ & - & $298.8(4)$ & 5 & 42 & $15-90$ \\
\hline gehlenite & $\mathbf{Q}$ & $P \overline{4} 2_{1} m$ & 2264 & $\mathrm{CH} 1$ & $7.708(2)$ & - & $5.054(2)$ & - & $300.3(2)$ & 9 & 51 & $10-80$ \\
\hline gehlenite & $Q$ & $P \overline{4} 2_{1} m$ & 2301 & $\mathrm{CH} 3$ & $7.728(1)$ & - & $5.044(1)$ & - & $301.2(5)$ & 9 & 50 & $10-80$ \\
\hline wollastonite & M & $P 2_{1} / a$ & P 77 & $\mathrm{CH} 1$ & $15.433(3)$ & $7.328(2)$ & $7.073(1)$ & $95.37(1)$ & $796.4(1)$ & 7 & 98 & $10-80$ \\
\hline wollastonite & M & $P 2_{1} / a$ & 2305 & CH 3 & $15.400(5)$ & $7.318(3)$ & $7.061(2)$ & $95.31(2)$ & $792.3(3)$ & 4 & 94 & $10-80$ \\
\hline grossular & $\mathrm{C}$ & $I a 3 d$ & P 62 & CH 1 & $11.884(3)$ & - & - & - & $1678.7(1)$ & 5 & 31 & $20-90$ \\
\hline grossular & $\mathrm{C}$ & $\operatorname{Ia} 3 d$ & 2306 & $\mathrm{CH} 1$ & $11.859(3)$ & - & - & - & $1667.9(1)$ & 3 & 25 & $20-90$ \\
\hline andradite $^{(4)}$ & $\mathrm{C}$ & $I a 3 d$ & P 55 & $\mathrm{CH} 1$ & $12.004(1)$ & - & - & - & $1730.0(5)$ & 6 & 22 & $20-90$ \\
\hline vesuvianite & $\mathbf{Q}$ & $P 4 / n n c$ & P 61 & $\mathrm{CH} 1$ & $15.606(3)$ & - & $11.833(3)$ & - & $2881.9(6)$ & 7 & 77 & $5-65$ \\
\hline vesuvianite & $\mathbf{Q}$ & P4/mmc & P 62 & $\mathrm{CH} 1$ & $15.572(3)$ & - & $11.845(4)$ & - & $2872.3(4)$ & 10 & 86 & $5-65$ \\
\hline
\end{tabular}

(1) Number of cycles in the refinement. (2) Number of reflections used in the refinement. (3) Range of $2 \theta$ angles used in collecting the reflections. (4) Titaniferous. 
TABLE 2. CRYSTALLOGRAPHIC PARAMETERS OF SELECTED SECONDARY MINERALS IN THE CORNET HILL SKARNS

\begin{tabular}{|c|c|c|c|c|c|c|c|c|c|c|c|c|}
\hline Mineral & System & $\begin{array}{l}\text { Space } \\
\text { group }\end{array}$ & Sample & Zone & $a(\AA)$ & $b(\AA)$ & $c(\AA)$ & $\beta^{(0)}$ & $V\left(\AA^{3}\right)$ & $\underset{(1)}{n}$ & $\begin{array}{l}\mathrm{N} \\
\text { (2) }\end{array}$ & $\begin{array}{c}2 \theta \text { range } \\
\left({ }^{\circ}\right)^{(3)}\end{array}$ \\
\hline scawtite & $\mathbf{M}$ & $I 2 / m$ & 2162 & $\mathrm{CH} 3$ & $10.136(3)$ & $15.205(3)$ & $6.638(2)$ & $100.61(1)$ & $1005.6(2)$ & 8 & 59 & $10-70$ \\
\hline scawtite & $\mathbf{M}$ & $I 2 / m$ & 2315 & $\mathrm{CH} 3$ & $10.125(4)$ & $15.199(6)$ & $6.618(2)$ & $100.66(2)$ & $1000.8(5)$ & 10 & 88 & $10-70$ \\
\hline xonotlite & $\mathbf{M}$ & $P 2_{1} / a$ & 2170 & $\mathrm{CH} 1$ & $17.058(7)$ & $7.390(4)$ & $7.015(4)$ & $90.10(3)$ & $884.3(4)$ & 10 & 51 & $10-90$ \\
\hline xonotlite & $\mathbf{M}$ & $P 2_{1} / a$ & 2233 & $\mathrm{CH} 3$ & $17.033(9)$ & $7.364(4)$ & $7.043(4)$ & $90.00(4)$ & $883.4(4)$ & 8 & 38 & $10-90$ \\
\hline hibschite & $\mathrm{C}$ & $\operatorname{la} 3 d$ & P 55 & $\mathrm{CH} 3$ & $11.982(2)$ & - & - & - & $1720.3(1)$ & 3 & 21 & $15-90$ \\
\hline plombièrite & 0 & $\mathrm{Imm} 2$ & P 49 & $\mathrm{CH} 2$ & $5.613(5)$ & $3.672(3)$ & $27.981(23)$ & - & $576.7(2)$ & 4 & 31 & $5-75$ \\
\hline plombièrite & 0 & $\operatorname{Imm} 2$ & 2300 & $\mathrm{CH} 3$ & $5.624(4)$ & $3.667(3)$ & $28.037(20)$ & - & $578.3(6)$ & 3 & 31 & $5-75$ \\
\hline plombièrite & 0 & $\mathrm{Imm} 2$ & 2305 & $\mathrm{CH} 1$ & $5.632(4)$ & $3.674(3)$ & $28.031(37)$ & - & $580.1(8)$ & 6 & 28 & $5-75$ \\
\hline tobermorite & 0 & $\mathrm{C} 222_{1}$ & 2162 & $\mathrm{CH} 3$ & $11.253(2)$ & $7.365(8)$ & $22.716(26)$ & - & $1882.7(3)$ & 6 & 35 & $5-90$ \\
\hline tobermorite & 0 & $\mathrm{C}_{222} \mathrm{I}_{\mathrm{I}}$ & 2315 & $\mathrm{CH} 3$ & $11.194(3)$ & $7.386(2)$ & $22.778(8)$ & - & $1883.0(3)$ & 5 & 63 & $5-90$ \\
\hline riversideite & 0 & $P$ & 2300 & $\mathrm{CH} 3$ & $5.584(4)$ & $3.648(3)$ & $18.803(14)$ & - & $383.0(4)$ & 3 & 18 & $5-95$ \\
\hline riversideite & O & $P$ & 2315 & CH 3 & $5.572(6)$ & $3.646(3)$ & $18.789(13)$ & - & $381.7(4)$ & 3 & 19 & $5-95$ \\
\hline gismondine & $\mathbf{M}$ & $P 2_{1} / c$ & P 79 & $\mathrm{CH} 1$ & $10.013(5)$ & $10.609(3)$ & $9.846(3)$ & $92.33(2)$ & $1045.1(3)$ & 5 & 27 & $10-85$ \\
\hline portlandite & $\mathbf{H}$ & $P \overline{3} m 1$ & 2170 & CH 1 & $3.593(1)$ & - & $4.905(2)$ & - & $54.8(2)$ & 3 & 18 & $5-110$ \\
\hline aragonite & O & Pnma & 2176 & $\mathrm{CH} 2$ & $4.974(5)$ & $7.917(8)$ & $5.694(10)$ & - & $224.2(1)$ & 4 & 49 & $25-90$ \\
\hline aragonite & O & Pnma & 2315 & $\mathrm{CH} 3$ & $4.960(2)$ & $7.977(3)$ & $5.738(2)$ & - & $227.0(1)$ & 6 & 58 & $25-90$ \\
\hline calcite & $\mathbf{R}$ & $R \overline{3} c$ & 2171 & $\mathrm{CH} 1$ & $4.985(1)$ & - & $17.050(6)$ & - & $366.9(6)$ & 3 & 37 & $20-115$ \\
\hline calcite & $\mathbf{R}$ & $R \overline{3} c$ & 2176 & $\mathrm{CH} 2$ & $4.989(4)$ & - & $17.066(2)$ & - & $367.9(2)$ & 5 & 31 & $20-115$ \\
\hline calcite & $\mathbf{R}$ & $R \overline{3} c$ & 2300 & $\mathrm{CH} 3$ & $4.987(1)$ & - & $17.058(5)$ & - & $367.3(1)$ & 4 & 36 & $20-110$ \\
\hline
\end{tabular}

(1) Number of cycles in the refinement. (2) Number of reflections used in the refinement. (3) Range of $2 \theta$ angles used in collecting the reflections.

standard deviations given in Table $3\left(\mathrm{sd}=\sigma_{\mathrm{n}}\right)$ refers to the individual samples.

Tilleyite shows slight departures from the ideal stoichiometry. The main deviation is shown by the sum of octahedrally coordinated cations, which, in the case of normalization of the formula to 13 oxygen atoms, is slightly higher than $5 a p f u$ (atoms per formula unit), whereas the sum of tetrahedrally coordinated cations is lower than 2 apfu. The extent of (Mg, Mn, Fe)-for-Ca substitution is very limited; only up to $0.52 \%$ of the octahedral sites are occupied by cations other than $\mathrm{Ca}$.

\section{Spurrite}

Spurrite occurs as main component of the $\mathrm{CH} 2$ zone, in practically monomineralic masses of grayish blue to pale gray color. Individual grains generally exceed 5 $\mathrm{mm}$ in their largest dimension. The mineral is commonly extremely fresh, and the least-altered primary skarn mineral in the area. Some of the larger patches of spurrite are, however, cross-cut by microveins containing scawtite, plombièrite, tobermorite, calcite and secondary aragonite.

The $2 V$ angle determined by us $\left(39^{\circ}\right)$ is slightly smaller than that determined by Tilley (1929) for the spurrite from Scawt Hill $\left(40^{\circ}\right)$, but is identical with the value measured for this mineral by Istrate et al. (1978). The indices of refraction determined for a representative sample (2176a) are: $\alpha$ 1.637(2), $\beta$ (calc.) 1.675(2), $\gamma 1.680(3)$. The unit-cell parameters of two representative samples are given in Table 1. They are slightly larger than those reported for the sample used for structure refinement by Smith et al. (1960) [a 10.49(5), $b$ 6.705(50), c 14.16(5) $\mathrm{\AA}, \beta 101.32(8)^{\circ}$ ].

The chemical composition obtained as an average of four sets of analyses of spurrite samples is given in Table 3. The proportion of $\mathrm{CO}_{2}$ was deduced assuming a molar ratio $\mathrm{SiO}_{2}: \mathrm{CO}_{2}$ of $2: 1$, according to the crystalstructure refinement of Smith et al. (1960), and all individual compositions were normalized to $100 \mathrm{wt}$.\%. Unit formulae were normalized to 11 atoms of oxygen. The total of six-fold-coordinated cations does not significantly exceed the ideal $5 \mathrm{apfu}$. The abundances of Mn (<0.005 apfu), $\mathrm{Fe}(<0.008$ apfu $)$ and $\mathrm{Mg}(<0.005$ apfu $)$ are very low and agree perfectly with those observed in tilleyite.

\section{Wollastonite}

Wollastonite (the $2 M$ polytype) commonly occurs as subparallel bunches of acicular to rod-shaped crystals, which may be grouped in radial aggregates. The mineral is widespread in the $\mathrm{CH} 1$ zone, where it generally occurs in association with grossular, as loose aggregates of subparallel crystals, locally separated by parting zones occupied by xonotlite. Wollastonite may also be found in the $\mathrm{CH} 2$ and $\mathrm{CH} 3$ zones, as veins or nests (remnants?) hosted by the masses of spurrite or tilleyite. 
TABLE 3. REPRESENTATIVE COMPOSITIONS OF SOME HIGH-TEMPERATURE MINERALS, CORNET HILL, ROMANIA*

\begin{tabular}{|c|c|c|c|c|c|c|c|c|}
\hline $\begin{array}{l}\text { Species }{ }^{(1)} \\
\text { Zone } \\
\mathrm{n}^{(2)} \\
\mathrm{N}^{(3)}\end{array}$ & $\begin{array}{c}\text { tilleyite } \\
\text { CH } 3 \\
14 \\
115\end{array}$ & sd & $\begin{array}{c}\text { spurite } \\
\mathrm{CH} 2 \\
4 \\
23\end{array}$ & sd & $\begin{array}{c}\text { wo } \\
\text { CH } 1 \\
5 \\
16\end{array}$ & sd & $\begin{array}{c}\text { wo } \\
\text { CH } 3 \\
2 \\
6\end{array}$ & sd \\
\hline $\mathrm{SiO}_{2}$ wt. $\%$ & 24.46 & 0.47 & 26.84 & 0.07 & 51.55 & 0.31 & 51.37 & 0.10 \\
\hline $\mathrm{TiO}_{2}$ & 0.03 & 0.03 & 0.03 & 0.02 & - & - & - & - \\
\hline $\mathrm{Al}_{2} \mathrm{O}_{3}$ & 0.00 & 0.00 & 0.01 & 0.01 & 0.12 & 0.09 & 0.18 & 0.03 \\
\hline $\mathrm{FeO}^{(4)}$ & 0.05 & 0.07 & 0.03 & 0.02 & 0.04 & 0.02 & 0.04 & 0.02 \\
\hline $\mathrm{MgO}$ & 0.04 & 0.02 & 0.02 & 0.01 & 0.09 & 0.03 & 0.08 & 0.02 \\
\hline $\mathrm{MnO}$ & 0.03 & 0.01 & 0.05 & 0.02 & 0.02 & 0.02 & 0.03 & 0.02 \\
\hline $\mathrm{CaO}$ & 57.12 & 1.46 & 63.11 & 0.09 & 48.02 & 0.29 & 48.15 & 0.14 \\
\hline $\mathrm{Na}_{2} \mathrm{O}$ & 0.01 & 0.01 & 0.07 & 0.01 & 0.01 & 0.01 & 0.01 & 0,01 \\
\hline $\mathrm{K}_{2} \mathrm{O}$ & 0.01 & 0.01 & 0.01 & 0.00 & 0.01 & 0.01 & 0.00 & 0.00 \\
\hline $\mathrm{CO}_{2}{ }^{(5)}$ & 17.92 & 0.34 & 9.83 & 0.03 & - & - & - & - \\
\hline Total & 99.67 & 2.20 & 100.00 & 0.00 & 99.86 & 0.44 & 99.86 & 0.00 \\
\hline \multicolumn{9}{|c|}{ Number of cations on the basis of $X(0)^{(6)}$} \\
\hline Si apfu & 1.997 & 0.011 & 1.990 & 0.004 & 5.987 & 0.017 & 5.973 & 0.008 \\
\hline $\mathrm{Ti}$ & 0.002 & 0.002 & 0.002 & 0.001 & - & - & - & - \\
\hline $\mathrm{Al}$ & 0.000 & 0.000 & 0.001 & 0.001 & 0.017 & 0.013 & 0.024 & 0.003 \\
\hline $\mathrm{Fe}^{2-}$ & 0.004 & 0.004 & 0.002 & 0.002 & 0.004 & 0.002 & 0.004 & 0.002 \\
\hline $\mathrm{Mg}$ & 0.004 & 0.002 & 0.002 & 0.001 & 0.016 & 0.006 & 0.014 & 0.004 \\
\hline Mn & 0.002 & 0.001 & 0.003 & 0.001 & 0.002 & 0.002 & 0.003 & 0.002 \\
\hline $\mathrm{Ca}$ & 4.996 & 0.046 & 5.013 & 0.010 & 5.975 & 0.033 & 5.998 & 0.022 \\
\hline $\mathrm{Na}$ & 0.002 & 0.001 & 0.011 & 0.002 & 0.002 & 0.003 & 0.001 & 0.001 \\
\hline K & 0.001 & 0.001 & 0.001 & 0.000 & 0.002 & 0.002 & 0.000 & 0.000 \\
\hline C & 1.997 & 0.011 & 0.995 & 0.002 & - & - & - & - \\
\hline$\Sigma$ cations & 9.005 & 0.024 & 8.019 & 0.006 & 12.005 & 0.009 & 12.017 & 0.007 \\
\hline
\end{tabular}

* Results of electron-microprobe analyses. (1) wo = wollastonite. (2) Number of samples. (3) Number of point analyses. (4) Total iron expressed as $\mathrm{FeO}$. (5) As calculated from stoichiometry. (6) $X=13$ for tilleyite, $X=11$ for spurrite, $X=18$ for wollastonite apfu: atoms per formula unit.

The average chemical composition of seven representative samples is given in Table 3 , whereas representative unit-cell parameters are given in Table 1 . The composition conforms closely to the expected stoichiometry. No significant compositional variation is observed within single crystals. Despite the variety of occurrences (i.e., position with respect to contact), the composition is remarkably uniform, with $\mathrm{Mn}<0.005$ apfu, $\mathrm{Fe}^{2+}<0.007$ apfu and $\mathrm{Mg}<0.022$ apfu.

\section{Gehlenite}

Gehlenite is a substantial component of the $\mathrm{CH} 1$ zone, but clusters of gehlenite crystals interstitial to tilleyite in $\mathrm{CH} 3$ or to spurrite in $\mathrm{CH} 2$ are common (Fig. 2A). They are very irregularly distributed and probably express the former presence of Al-bearing silicate veins or beds in the protolith. In all zones and particularly in $\mathrm{CH} \mathrm{1,} \mathrm{the} \mathrm{crystals} \mathrm{may} \mathrm{be} \mathrm{found} \mathrm{embedded}$ in a matrix of vesuvianite, and the cleavages of gehlenite are in some cases filled with vesuvianite, which is probably the result of the interaction between the gehlenite and a late-stage aqueous fluid.

The density of a representative sample (2167 from $\mathrm{CH}$ 1), determined by heavy-liquid methods, is 3.065(2) $\mathrm{g} / \mathrm{cm}^{3}$, in excellent agreement with the calculated value $D_{\mathrm{x}}=3.069 \mathrm{~g} / \mathrm{cm}^{3}$. The indices of refraction of the same sample are: $\omega$ 1.660(2), $\varepsilon$ 1.655(1).

The cell parameters (Table 1) are evidently influenced by the chemical variability. In particular, for the samples whose chemical compositions are given in Table 4, the solid solutions toward åkermanite vary from $\mathrm{Ak}_{25.7}$ to $\mathrm{Ak}_{40.9}$. Within individual samples, the compositional variation rarely exceeds 5 mol.\% of individual end-members. Slight core-to-rim compositional variations may be observed in most of the grains, which generally show an outward increase in the amount of the åkermanite component. The highest $\mathrm{Mg}$ contents are observed in gehlenite from the outer skarn zone $\mathrm{CH} 3$ (Fig. 3). The sum of tetrahedrally coordinated cations in the two sites described by Louisnathan (1971) tends to be low, associated with high totals of the eight-fold coordinated cations, suggesting that part of the Ca atoms may also occupy the tetrahedral $T$ ' sites (Table 4).

\section{Garnet}

Garnet is found dominantly in the $\mathrm{CH} 1$ zone and, to a lesser degree, in $\mathrm{CH} 2$ and $\mathrm{CH} 3$ zones. Euhedral to subhedral crystals average $<1 \mathrm{~mm}$ across in the latter, but attain up to $8 \mathrm{~mm}$ in the $\mathrm{CH} 1$ zone. Several generations of garnet may be recognized on the basis of textural relationships. A representative set of electron-microprobe results is given in Table 5 . The number of ions was calculated on the basis of $(\mathrm{Ca}+\mathrm{Fe}+\mathrm{Ti}+\mathrm{Al}+\mathrm{Mg}$ $+\mathrm{Mn}+\mathrm{Na})=5$ apfu, as recommended by Armbruster et al. (1998) for andradite with an assumed significant hydrogarnet component. This basis of normalization was maintained for all samples, for homogeneity. The hydrogarnet component is perceptible (Table 5), such that the method of Droop (1987) for estimating $\mathrm{Fe}^{3+}$ is inappropriate. This method was used, however, for the Ti-poor samples 2163 and 2176, where the substitution toward schorlomite $\left(\mathrm{Si}^{4+} \leftrightarrow \mathrm{Ti}^{4+}\right)$ must prevail over the substitution toward morimotoite $\left(\mathrm{Fe}^{2+}+\mathrm{Ti}^{4+} \leftrightarrow 2 \mathrm{Fe}^{3+}\right)$. In all other samples, the substitution toward morimotoite was taken into consideration, and the proportion of $\mathrm{Fe}^{2+}$ was calculated in order to equalize $\mathrm{Ti}^{4+}$ (apfu), as recommended by Armbruster et al. (1998).

The compositions (Table 5) cover a large interval of grossular - andradite solid solution, with variable $\mathrm{Ti}$ content. A first generation of garnet (anal. 1 and 2, Table 5) consists of Ti-poor grossular, in fact a solid solution of grossular (74.1-81.0 mol.\% Grs), andradite (25.2-11.5 mol.\% Adr), and minor "pyralspite" (0.8$7.5 \mathrm{~mol} . \%)$; this generation of garnet is considered by Pascal et al. (2001) to be in equilibrium with gehlenite. It generally occurs as inclusions in gehlenite, and rarely appear within the gehlenite crystals as an atoll-like array of star-shaped crystals. With few exceptions, this grossular does not exhibit any intragranular compositional zonation and is sufficiently Si-depleted to assume incorporation of a hydrogarnet component. Where 
TABLE 4. REPRESENTATIVE COMPOSITIONS OF GEHLENITE, CORNET HILL, ROMANIA*

\begin{tabular}{|c|c|c|c|c|c|c|c|c|c|c|c|c|}
\hline Sample & P57 & 2161 & 2163 & 2167 & P49 & 2176 & P55 & 2162 & 2223 & 2259 & 2300 & 2315 \\
\hline Zone & $\mathrm{CH} 1$ & CH 1 & $\mathrm{CH} 1$ & $\mathrm{CH} 1$ & $\mathrm{CH} 2$ & $\mathrm{CH} 2$ & $\mathrm{CH} 3$ & $\mathrm{CH} 3$ & CH 3 & $\mathrm{CH} 3$ & $\mathrm{CH} 3$ & $\mathrm{CH} 3$ \\
\hline $\mathrm{N}^{(1)}$ & 4 & 12 & 7 & 10 & 5 & 3 & 7 & 7 & 3 & 5 & 3 & 3 \\
\hline $\mathrm{SiO}_{2}$ wt. $\%$ & 31.33 & 28.72 & 29.82 & 32.92 & 27.18 & 27.79 & 29.56 & 30.81 & 29.13 & 31.59 & 30.41 & 30.87 \\
\hline $\mathrm{TiO}_{2}$ & 00.02 & 0.04 & 0.04 & 0.08 & 0.01 & 0.00 & 0.01 & 0.05 & 0.00 & 0.05 & 0.00 & 0.04 \\
\hline $\mathrm{Al}_{2} \mathrm{O}_{3}$ & 21.62 & 23.22 & 22.49 & 21.71 & 26.87 & 25.83 & 23.29 & 22.13 & 22.06 & 21.24 & 23.49 & 20.42 \\
\hline $\mathrm{FeO}^{(2)}$ & 0.36 & 1.24 & 0.53 & 0.55 & 0.64 & 1.04 & 1.10 & 0.83 & 1.18 & 1.06 & 1,24 & 1.02 \\
\hline $\mathrm{MgO}$ & 5.04 & 4.30 & 3.97 & 3.70 & 3.10 & 3.51 & 4.37 & 4.12 & 3.97 & 5.49 & 4.62 & 5.55 \\
\hline $\mathrm{MnO}$ & 0.03 & 0.07 & 0.07 & 0.03 & 0.03 & 0.09 & 0.05 & 0.07 & 0.01 & 0.05 & 0.07 & 0.05 \\
\hline $\mathrm{CaO}$ & 40.35 & 40.24 & 39.49 & 39.11 & 41.12 & 40.35 & 40.63 & 38.34 & 40.44 & 39.61 & 40.39 & 40.12 \\
\hline $\mathrm{Na}_{2} \mathrm{O}$ & 0.70 & 0.38 & 0.61 & 0.71 & 0.25 & 0.35 & 0.50 & 0.28 & 0.28 & 0.41 & 0.26 & 0.42 \\
\hline $\mathrm{K}_{2} \mathrm{O}$ & 0.00 & 0.01 & 0.00 & 0.02 & 0.02 & 0.01 & 0.01 & 0.01 & 0.01 & 0.00 & 0.00 & 0.01 \\
\hline Total & 99.45 & 98.22 & 97.02 & 98.83 & 99.22 & 98.97 & 99.52 & 96.64 & 97.08 & 99.50 & 100.48 & 98.50 \\
\hline \multicolumn{13}{|c|}{ Number of cations on the basis of $14(\mathrm{O})$} \\
\hline Si apfu & 2.873 & 2.689 & 2.806 & 3.013 & 2.514 & 2.577 & 2.726 & 2.894 & 2.760 & 2.895 & 2.767 & 2.872 \\
\hline $\mathrm{Al}$ & 1.127 & 1.311 & 1.194 & 0.987 & 1.486 & 1.423 & 1.274 & 1.106 & 1.240 & 1.105 & 1.233 & 1.128 \\
\hline$T$ sites & 4.000 & 4.000 & 4.000 & 4.000 & 4.000 & 4.000 & 4.000 & 4.000 & 4.000 & 4.000 & 4.000 & 4.000 \\
\hline $\mathrm{Ti}$ & 0.001 & 0.003 & 0.003 & 0.006 & 0.001 & 0.000 & 0.001 & 0.004 & 0.000 & 0.003 & 0.000 & 0.003 \\
\hline Al & 1.210 & 1.251 & 1.300 & 1.355 & 1.443 & 1.399 & 1.257 & 1.344 & 1.223 & 1. 189 & 1.286 & 1.111 \\
\hline $\mathrm{Fe}^{2+}$ & 0.028 & 0.097 & 0.042 & 0.042 & 0.050 & 0.081 & 0.085 & 0.065 & 0.093 & 0.081 & 0.094 & 0.079 \\
\hline $\mathbf{M g}$ & 0.689 & 0.600 & 0.557 & 0.505 & 0.427 & 0.485 & 0.601 & 0.577 & 0.561 & 0.750 & 0.627 & 0.770 \\
\hline $\mathrm{Mn}$ & 0.002 & 0.006 & 0.006 & 0.002 & 0.002 & 0.007 & 0.004 & 0.006 & 0.001 & 0.004 & 0.005 & 0.004 \\
\hline$T$ sites & 1.929 & 1.957 & 1.908 & 1.910 & 1.923 & 1.972 & 1.948 & 1.996 & 1.878 & 2.027 & 2.012 & 1.967 \\
\hline $\mathrm{Ca}$ & 3.965 & 4.036 & 3.981 & 3.836 & 4.075 & 4.008 & 4.015 & 3.858 & 4.105 & 3.890 & 3.938 & 3.999 \\
\hline $\mathrm{Na}$ & 0.124 & 0.069 & 0.111 & 0.126 & 0.045 & 0.063 & 0.089 & 0.051 & 0.051 & 0.073 & 0.046 & 0.076 \\
\hline $\mathbf{K}$ & 0.000 & 0.001 & 0.000 & 0.002 & 0.002 & 0.001 & 0.001 & 0.001 & 0.001 & 0.000 & 0.000 & 0.001 \\
\hline O sites & 4.089 & 4.106 & 4.092 & 3.964 & 4.122 & 4.072 & 4.105 & 3.910 & 4.157 & 3.963 & 3.984 & 4.076 \\
\hline$\Sigma$ cations & 10.019 & 10.063 & 10.000 & 9.874 & 10.045 & 10.044 & 10.053 & 9.906 & 10.035 & 9.990 & 9.996 & 10.043 \\
\hline \multicolumn{13}{|c|}{ Composition in terms of end-members (mol. \%) } \\
\hline Geh & 63.72 & 67.59 & 70.01 & 72.85 & 77.17 & 74.26 & 67.65 & 69.96 & 68.55 & 61.32 & 67.22 & 59.06 \\
\hline $\mathrm{Ak}$ & 36.28 & 32.41 & 29.99 & 27.15 & 28.83 & 25.74 & 32.35 & 30.04 & 31.45 & 38.68 & 32.78 & 40.94 \\
\hline
\end{tabular}

* Results of electron-microprobe analyses. (1) Number of point analyses. (2) Total iron expressed as FeO. apfu: atoms per formula unit.

zoned, it may compositionally evolve by a slight enrichment in $\mathrm{Fe}^{2+}$ toward the rim.

A second generation (anal. 3-6, Table 5), also encountered mainly in the $\mathrm{CH} 1$ zone, is Ti-bearing grossular. It occurs as small subhedral crystals that are generally associated with gehlenite and wollastonite, rarely with spurrite or tilleyite. The crystals are compositionally zoned, but the variations are very modest; Ti and $\mathrm{Fe}$ are slightly enriched in the outer zones. The composition generally corresponds to grossular (53.2-75.1 mol.\% Grs), with low andradite (36.2-20.2 mol.\% Adr) and morimotoite (8.5-3.0 mol.\% Mor). A third generation of garnet (anal. 7 to 11 , Table 5) is a titanian andradite that develops in subhedral to euhedral crystals up to $8 \mathrm{~mm}$ in diameter and generally displays a rimward increase in both andradite and morimotoite contents, compensated by a slight decrease of the grossular con- tent. This garnet appears to replace perovskite locally. The mean chemical compositions (Table 5) indicate an andradite (48.0-62.1 mol.\% Adr), with significant grossular (27.2-34.3 mol.\% Grs) and high morimotoite components (21.4-8.4 mol.\% Mor). The overall composition of each generation of garnet varies considerably, but not enough to change the general trend established on the basis of the data in Table 5. Representative cell parameters obtained for calcic garnets from Cornet Hill are given in Table 1 . They show the increase in $a$ due to the incorporation of morimotoite, which is very clear in the case of sample P 55.

\section{Vesuvianite}

Vesuvianite was found as product of both primary and late-stage metasomatism, at which point this min- 

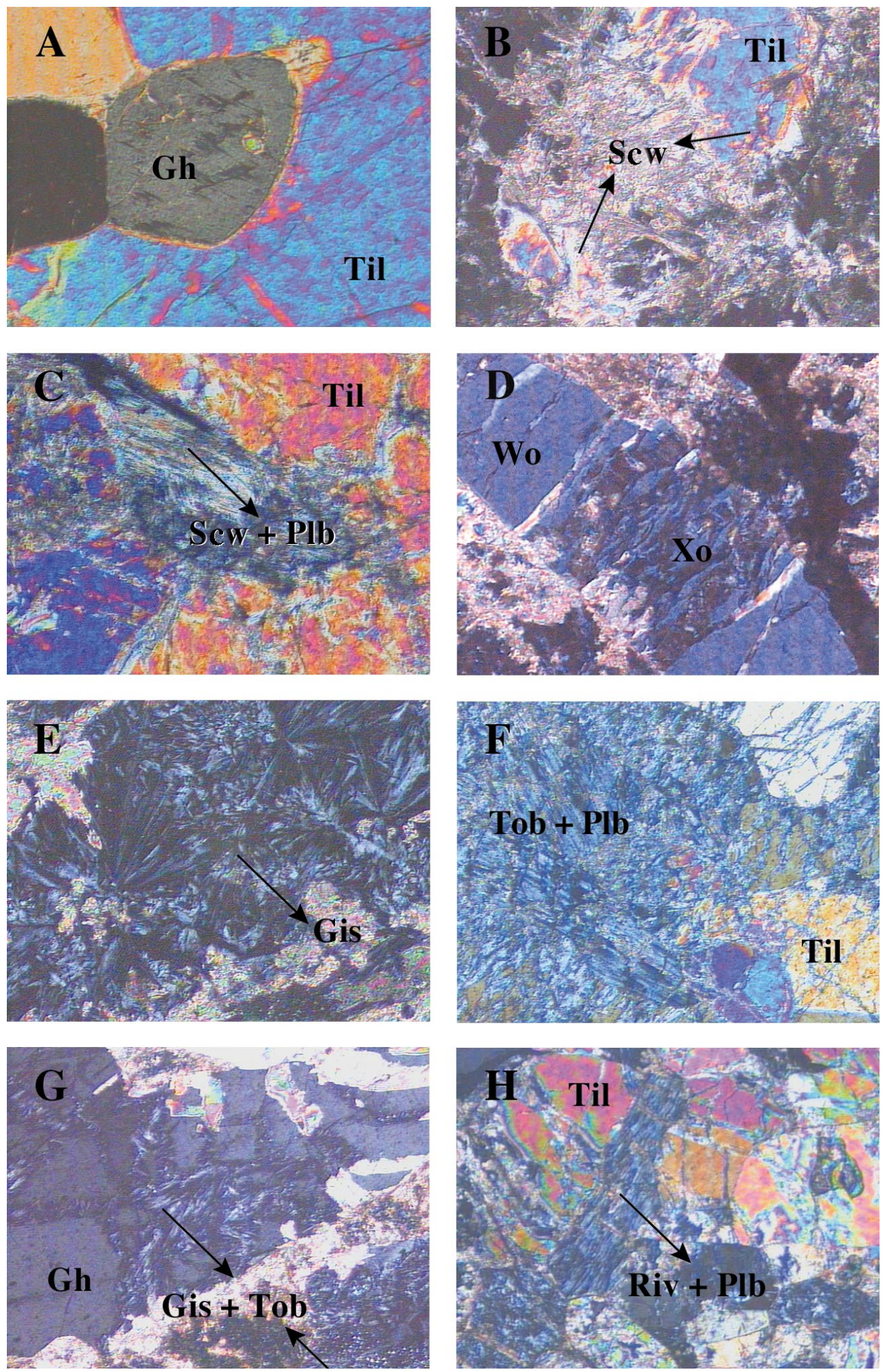
eral partially replaces gehlenite. Vesuvianite is most abundant in the $\mathrm{CH} 1$ zone.

Electron-microprobe traverses across crystals of both vesuvianite without reciprocal relationships with gehlenite and vesuvianite from replacement pods on gehlenite reveal a slight increase in $\mathrm{Al} / \mathrm{Fe}$ from core to rim. Average compositions, taken as means of two to five randomly distributed point-analyses within a crystal, are presented in Table 6. As electron-microprobe checks for boron revealed that vesuvianite from Cornet Hill is boron-free, the formulae in Table 6 were calculated on the basis of 50 cations $p f u$, as recommended by Groat et al. (1992).

\section{Other minerals}

Perovskite is rare in the association from Cornet Hill, where it was only found as an inclusion phase in gehlenite, garnet or spurrite, mostly in the $\mathrm{CH} 1$ and $\mathrm{CH}$ 2 zones. The mineral invariably forms euhedral or subhedral crystals of pseudocubic or pseudo-octahedral habit. The crystals range in size from 0.01 to $0.05 \mathrm{~mm}$. Perovskite is locally rimmed, or partly replaced, by titanian andradite.

Monticellite seems to be very rare, as it was identified only in few patches. It occurs mostly in the $\mathrm{CH} 1$ zone, as a network of discontinuous veinlets between the gehlenite crystals or, more rarely, as euhedral inclusions in gehlenite.

Diopside occurs as texturally late crystals dispersed in or forming veinlets that usually cross-cut the wollastonite-bearing skarn in the $\mathrm{CH} 1$ zone. Scarce veinlets of diopside, up to $0.5 \mathrm{~cm}$ wide, cut straight across all zones. These veinlets are not altered, do not induce any alteration, and are clearly late, since they postdate all primary metasomatic textures. The diopside from Cornet Hill is relatively Al-rich, containing up to $19.4 \mathrm{wt} . \%$ $\mathrm{Al}_{2} \mathrm{O}_{3}$ (Pascal et al. 2001).

FIG. 2. Photomicrographs showing characteristic relationships among minerals in the high-temperature skarn at Cornet Hill. Transmitted light, crossed nicols. Width of field of view: $2.6 \mathrm{~mm}$. (A) Gehlenite (Gh) surrounded by tilleyite (Til). CH 3 zone. (B) Thin seams of scawtite (Scw) bordering tilleyite crystals. $\mathrm{CH} 3$ zone. (C) Aggregate of scawtite and plombièrite engulfed in the tilleyite mass. $\mathrm{CH}$ 3 zone. (D) Xonotlite (Xo) in a zone of parting that breaks up a crystal of wollastonite (Wo). CH 1 zone. (E) Fanshaped aggregates of gismondine (Gis) on a fissure that affects the gehlenite + wollastonite mass. $\mathrm{CH} 1$ zone. (F) Bunches of needle-like crystals of tobermorite (Tob) and plombièrite $(\mathrm{Plb})$ on a fissure affecting a mass of tilleyite. $\mathrm{CH} 3$ zone. (G) Fan-like aggregates of gismondine and Alrich tobermorite lining gehlenite crystals. $\mathrm{CH} 1$ zone. $(\mathrm{H})$ Aggregate of riversideite (Riv) + plombièrite on a fissure affecting tilleyite. $\mathrm{CH} 3$ zone. Both phases were identified by XRD.
Hydroxylellestadite occurs ubiquitously as euhedral to subhedral short prismatic crystals embedded in tilleyite masses in $\mathrm{CH} 3$ zone or coexisting with gehlenite in $\mathrm{CH} 1$ zone (the $\mathrm{C} 2$ association described by Pascal et al. 2001). The crystals range in size from 0.1 to $0.6 \mathrm{~mm}$.

\section{Alteration Minerals and Their Parageneses}

The secondary minerals described below are only those that were positively identified in an X-ray powder-diffraction study, combined with optical data and electron-microprobe analyses. Stoichiometries corresponding to some other phases (i.e., afwillite or jennite, foshagite or jaffeite, mountainite, cebollite) were recognized, but the lack of positive $\mathrm{X}$-ray identifications and the local occurrence of $\mathrm{CaO}-\mathrm{SiO}_{2}-\mathrm{H}_{2} \mathrm{O} \pm \mathrm{Al}_{2} \mathrm{O}_{3}$ gels of variable stoichiometry preclude a definitive statement.

\section{Scawtite}

Scawtite forms bright white encrustations on tilleyite and, together with plombièrite, calcite and tobermorite, occur as fillings of the fractures traversing tilleyite. A thin seam of scawtite always lines the tilleyite grains (Fig. 2B). Note that scawtite is commonly documented as a product of primary alteration of spurrite (e.g., Tilley 1938, McConnell 1955), which is not the case at Cornet Hill, where this mineral is the main product of alter-
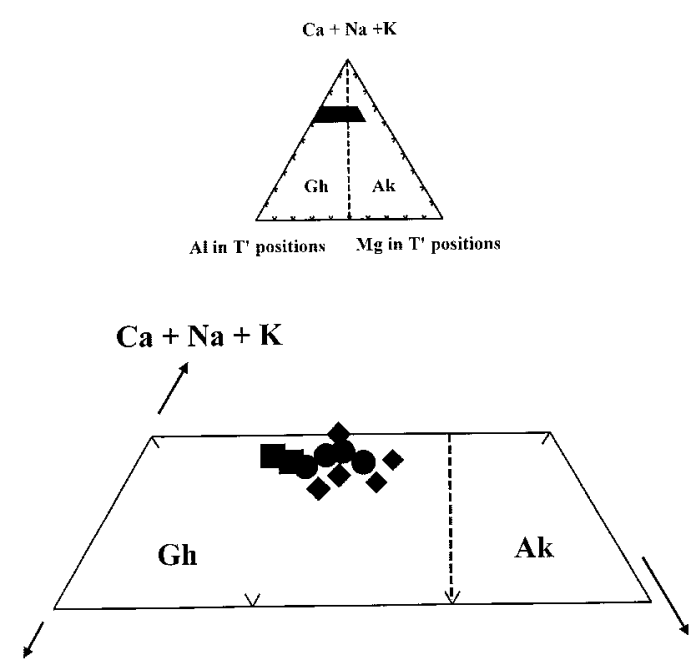

Al in $T^{\prime}$ positions

Mg in $\mathbf{T}^{\prime \prime}$ positions

FIG. 3. Diagram showing the extent of solid solution of the gehlenite in the gehlenite - åkermanite series at Cornet Hill. Samples from CH 1 (solid circles), $\mathrm{CH} 2$ (solid squares) and $\mathrm{CH} 3$ (diamonds) zones. Gh: the gehlenite field; Ak: the åkermanite field. 
TABLE 5. REPRESENTATIVE COMPOSITIONS OF CALCIC GARNET, CORNET HILL, ROMANIA*

\begin{tabular}{|c|c|c|c|c|c|c|c|c|c|c|c|}
\hline Sample & 2163 & 2176 & 2167 & 2306 & P57 & P55 & 2176 & 2173 & 2265 & 2305 & P55 \\
\hline Zone & $\mathrm{CH} 1$ & $\mathrm{CH} 2$ & $\mathrm{CH} 1$ & $\mathrm{CH} 1$ & $\mathrm{CH} 1$ & $\mathrm{CH} 3$ & $\mathrm{CH} 2$ & $\mathrm{CH}_{3}$ & $\mathrm{CH}_{3}$ & $\mathrm{CH} 3$ & $\mathrm{CH}_{3}$ \\
\hline $\mathrm{N}^{(1)}$ & 4 & 3 & 6 & 9 & 3 & 3 & 4 & 3 & 3 & 6 & 8 \\
\hline $\mathrm{SiO}_{2}$ wt. $\%$ & 39.21 & 36.79 & 37.50 & 38.40 & 36.47 & 37.61 & 34.32 & 34.29 & 34.82 & 33.7 & 32.09 \\
\hline $\mathrm{TiO}_{2}$ & 0.15 & 0.18 & 1.65 & 0.96 & 2.70 & 1.06 & 2.58 & 4.76 & 3.18 & 5.74 & 6.46 \\
\hline $\mathrm{Al}_{2} \mathrm{O}_{3}$ & 17.58 & 16.29 & 15.71 & 15.97 & 11.26 & 13.07 & 5.83 & 6.93 & 5.54 & 5.76 & 5.88 \\
\hline $\mathrm{Fe}_{2} \mathrm{O}_{3}(2)$ & 3.57 & 8.59 & 7.17 & 6.59 & 11.52 & 11.54 & 19.16 & 14.61 & 18.53 & 14.75 & 14.45 \\
\hline $\mathrm{FeO}$ (z) & 3.22 & 0.00 & 1.48 & 0.86 & 2.43 & 0.95 & 2.33 & 4.28 & 2.86 & 5.16 & 5.81 \\
\hline $\mathrm{MnO}$ & 0.02 & 0,00 & 0.09 & 0.09 & 0.09 & 0.01 & 0.04 & 0.03 & 0.13 & 0.03 & 0.07 \\
\hline $\mathrm{MgO}$ & 0.33 & 0.20 & 0.48 & 0.41 & 0.50 & 0.27 & 0.20 & 0.38 & 0.27 & 0.43 & 0.48 \\
\hline $\mathrm{CaO}$ & 36.77 & 36.83 & 35.73 & 36.24 & 35.40 & 36.17 & 35.28 & 33.94 & 33.70 & 34.25 & 33.99 \\
\hline $\mathrm{Na}_{2} \mathrm{O}$ & 0.02 & 0.01 & 0.01 & 0.02 & 0.02 & 0.01 & 0.01 & 0.05 & 0.00 & 0.01 & 0.00 \\
\hline Total & 100.87 & 98.89 & 99.82 & 99.54 & 100.39 & 100.69 & 99.75 & 99.27 & 99.03 & 99.83 & 99.23 \\
\hline \multicolumn{12}{|c|}{ Number of ions on the basis of $5(\mathrm{Ca}+\mathrm{Fe}+\mathrm{Ti}+\mathrm{Al}+\mathrm{Mg}+\mathrm{Mn}+\mathrm{Na})$} \\
\hline Si $a p f u$ & 2.963 & 2.805 & 2.863 & 2.964 & $\quad 2.814$ & 2.899 & 2.710 & 2.705 & 2.814 & 2.637 & 2.479 \\
\hline $\mathrm{Ti}$ & 0.009 & 0.010 & 0.095 & 0.056 & 0.157 & 0.061 & 0.153 & 0.282 & 0.193 & 0.338 & 0.375 \\
\hline Al & 1.566 & 1.464 & 1414 & 1.453 & 1.024 & 1.187 & 0.542 & 0.644 & 0.528 & 0.531 & 0.535 \\
\hline $\mathrm{Fe}^{3+}$ & 0.203 & 0.493 & 0.412 & 0.383 & 0.669 & 0.669 & 1.138 & 0.867 & 1.127 & 0.868 & 0.840 \\
\hline $\mathrm{Fe}^{2+}$ & 0.204 & 0.000 & 0.095 & 0.056 & 0.157 & 0.061 & 0.153 & 0.282 & 0.193 & 0.338 & 0.375 \\
\hline $\mathrm{Mn}$ & 0.001 & 0.000 & 0.006 & 0.006 & 0.006 & 0.001 & 0.003 & 0.002 & 0.009 & 0.002 & 0.005 \\
\hline $\mathrm{Mg}$ & 0.037 & 0.023 & 0.054 & 0.047 & 0.058 & 0.031 & 0.024 & 0.045 & 0.033 & 0.050 & 0.055 \\
\hline $\mathrm{Ca}$ & 2.978 & 3.009 & 2.923 & 2.997 & 2.927 & 2.988 & 2.985 & 2.869 & 2.917 & 2.871 & 2.815 \\
\hline $\mathrm{Na}$ & 0.002 & 0.001 & 0.001 & 0.003 & 0.002 & 0.002 & 0.002 & 0.009 & 0.000 & 0.002 & 0.000 \\
\hline $\mathrm{O}$ & 11.819 & 11.598 & 11.734 & 11.900 & 11.631 & 11.786 & 11.412 & 11.443 & 11.649 & 11.311 & 11.021 \\
\hline$(\mathrm{OH})^{-(3)}$ & 0.362 & 0.804 & 0.532 & 0.200 & 0.738 & 0.428 & 1.176 & 1.114 & 0.702 & 1.378 & 1.958 \\
\hline$(\mathrm{OH})^{-(4)}$ & 0.148 & 0.780 & 0.548 & 0.144 & 0.744 & 0.404 & 1.160 & 1.180 & 0.744 & 1.452 & 2.084 \\
\hline \multicolumn{12}{|c|}{ Composition recast as end-members (mol.\%) ${ }^{(5)}$} \\
\hline Grs & 81.01 & 74.05 & 71.59 & 75.06 & 53.21 & 60.86 & 28.67 & 34.31 & 27,16 & 28.79 & 28.50 \\
\hline $\mathrm{Adr}$ & 11.47 & 25.19 & 21.45 & 20.24 & 36.16 & 34.90 & 62.08 & 48.35 & 60.98 & 49.97 & 48.00 \\
\hline Mor & 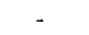 & - & 4.95 & 2.96 & 8,49 & 3.18 & 8.35 & 15.73 & 10.44 & 19.46 & 21.42 \\
\hline Prp & 1.15 & 0.76 & 1.81 & 1.54 & 1.94 & 1.03 & 0.80 & 1.54 & 1.12 & 1.71 & 1.91 \\
\hline Alm & 6.34 & - & - & - & - & - & - & - & - & - & - \\
\hline Sps & 0.03 & - & 0.20 & 0.20 & 0.20 & 0.03 & 0.10 & 0.07 & 0.30 & 0.07 & 0.17 \\
\hline
\end{tabular}

* Results of electron-microprobe analyses. (1) Number of point analyses. (2) As deduced from total iron (see text). (3) As deduced from the $\mathrm{O}^{2-}$ contents, for $[\mathrm{O}+(\mathrm{OH})]=12$ apfic. (4) As deduced from the Si contents, for $\left[\mathrm{Si}+(\mathrm{OH})_{4}\right]=3 a p f u$. (5) Except for Mor, for morimotoite, symbols after Kretz (1983). apfu: atoms for formula unit.

ation of tilleyite. It generally occurs as fibrous clusters that spread out from cracks and as discrete radiating crystals, being identical with the scawtite from Carneal (Northern Ireland) described by Sabine \& Young (1975); it may also occur as secondary fibrous masses scattered among the tilleyite grains (Fig. 2C). The textural relations, on the whole, strongly indicate that scawtite preceded both tobermorite and plombièrite. From evidence at the SEM scale, scawtite seems to be the early-formed phase, but is later transformed in calcite + tobermorite or calcite + plombièrite.

The indices of refraction, measured in immersion as maximum and minimum values, are 1.617(5) and 1.600(3), respectively. The cell dimensions determined for two representative samples of scawtite from Cornet Hill are listed in Table 2; these are refined in space group $I 2 / m$ ( $c f$. Murdoch 1955, Pluth \& Smith 1973). The samples used for the study were separated by hand-picking, followed by a rapid etching with diluted acetic acid in order to reduce the proportion of the remaining calcite, plombièrite and tobermorite. All these phases are readily soluble in acetic acid, but various rates of dissolution may be observed. Both plombièrite and tobermorite are more reactive with acetic acid than scawtite, and dissolve as quickly as the associated calcite.

The scawtite that overgrowths tilleyite crystals is highly calcic (Table 7). There was insufficient material totally free from impurities for a determination of $\mathrm{H}_{2} \mathrm{O}$ and $\mathrm{CO}_{2}$ contents; the two constituents were consequently calculated assuming stoichiometry. As the initial sums were very variable, totals were recalculated to $100 \%$. The structural formulae are based on the structure determined by Pluth \& Smith (1973) and Zhang et al. (1992); they were calculated on the basis of 21 at- 
TABLE 6. REPRESENTATIVE COMPOSITIONS OF VESUVIANTTE, CORNET HILL, ROMANIA*

\begin{tabular}{|c|c|c|c|c|c|c|c|}
\hline Sample & P57 & 2161 & 2264 & P55 & 2259 & 2173 & 2305 \\
\hline Zone & $\mathrm{CH} 1$ & $\mathrm{CH} 1$ & $\mathrm{CH} 1$ & $\mathrm{CH} 3$ & $\mathrm{CH} 3$ & $\mathrm{CH} 3$ & $\mathrm{CH} 3$ \\
\hline $\mathrm{N}^{(1)}$ & 2 & 3 & 4 & 3 & 5 & 5 & 5 \\
\hline $\mathrm{SiO}_{2} \mathrm{wt} \%$ & 36.46 & 35.91 & 36.05 & 37.98 & 36.26 & 37.12 & 36.38 \\
\hline $\mathrm{Al}_{2} \mathrm{O}_{3}$ & 18.38 & 19.51 & 18.35 & 17.27 & 18.42 & 17.66 & 18.59 \\
\hline $\mathrm{TiO}_{2}$ & 0.02 & 0.00 & 0.02 & 0.00 & 0.04 & 0.00 & 0.05 \\
\hline $\mathrm{MgO}$ & 5.04 & 3.48 & 4.25 & 4.06 & 3.45 & 4.23 & 4.69 \\
\hline MnO & 0.04 & 0.00 & 0.01 & 0.04 & 0.04 & 0.01 & 0.04 \\
\hline $\mathrm{FeO}^{(2)}$ & 0.26 & 0.75 & 2.03 & 1.22 & 2.06 & 0.65 & 0.88 \\
\hline $\mathrm{CaO}$ & 37.67 & 37.47 & 36.99 & 37.36 & 37.14 & 37.41 & 36.86 \\
\hline $\mathrm{Na}_{2} \mathrm{O}$ & 0.01 & 0.25 & 0.09 & 0.00 & 0.02 & 0.42 & 0.07 \\
\hline $\mathrm{K}_{2} \mathrm{O}$ & 0.00 & 0.03 & 0.28 & 0.00 & 0.00 & 0.01 & 0.01 \\
\hline $\mathrm{F}$ & 0.00 & 0.29 & 0.00 & 0.00 & 0.00 & 0.07 & 0.06 \\
\hline $\mathrm{Cl}$ & 0.00 & 0.00 & 0.16 & 0.00 & 0.00 & 0.09 & 0.05 \\
\hline \multirow[t]{2}{*}{$\mathrm{H}_{2} \mathrm{O}^{(3)}$} & 2.40 & 2.17 & 2.49 & 2.03 & 2.23 & 2.31 & 2.25 \\
\hline & 100.28 & 99.86 & 100.72 & 99,96 & 99.66 & 99.98 & 99.93 \\
\hline $\mathrm{O}=\mathrm{F}, \mathrm{Cl}$ & -0.00 & -0.12 & -0.04 & -0.00 & -0.00 & -0.05 & -0.04 \\
\hline Total & 100.28 & 99.74 & 100.68 & 99.96 & 99.66 & 99.93 & 99.89 \\
\hline \multicolumn{8}{|c|}{ Number of ions on the basis of 50 cations and $76(\mathrm{O}, \mathrm{OH}, \mathrm{F}, \mathrm{Cl})$} \\
\hline Si apfu & 17.153 & 17.037 & 17.021 & 18.005 & 17.311 & 17.559 & 17.204 \\
\hline $\mathrm{Al}$ & 10.191 & 10.909 & 10.211 & 9.649 & 10.364 & 9.846 & 10.361 \\
\hline $\mathrm{Ti}$ & 0.007 & 0.000 & 0.007 & 0.000 & 0.014 & 0.000 & 0.018 \\
\hline $\mathrm{Mg}$ & 3.535 & 2.461 & 2.991 & 2.869 & 2.455 & 2.983 & 3.306 \\
\hline Mn & 0.016 & 0.000 & 0.004 & 0.016 & 0.016 & 0.004 & 0.016 \\
\hline $\mathrm{Fe}^{2+}$ & 0.102 & 0.298 & 0.802 & 0.484 & 0.822 & 0.257 & 0.348 \\
\hline $\mathrm{Ca}$ & 18.987 & 19.047 & 18.712 & 18.976 & 18.998 & 18.960 & 18.676 \\
\hline $\mathrm{Na}$ & 0.009 & 0.230 & 0,082 & 0.000 & 0.019 & 0.385 & 0.064 \\
\hline $\mathbf{K}$ & 0.000 & 0.018 & 0.169 & 0.000 & 0.000 & 0.006 & 0.006 \\
\hline $\mathrm{F}$ & 0.000 & 0.435 & 0.000 & 0.000 & 0.000 & 0.105 & 0.090 \\
\hline Cl & 0.000 & 0.000 & 0.128 & 0.000 & 0.000 & 0.072 & 0.040 \\
\hline$(\mathrm{OH})^{-}$ & 7.498 & 6.830 & 7.858 & 6.343 & 7.007 & 7.250 & 7.137 \\
\hline
\end{tabular}

* Results of electron-microprobe analyses. (1) Number of point analyses. (2) Total iron expressed as FeO. (3) As calculated for charge balance. apfu: atoms per formula unit.

oms of oxygen in the anhydrous part of the formula. The total cation contents per formula unit (Table 7) range from 13.970 to 14.018 (average $13.999 \mathrm{apfu}$ ), and the Si contents range from 5.986 to 6.030 (average 6.002 apfu), which indicates formulae very close to stoichiometry.

A parallel record of TGA, DTG and DSC curves of a separate containing tilleyite, scawtite and traces of plombièrite (sample $\mathrm{P}$ 55) show that, after evolving (molecular) $\mathrm{H}_{2} \mathrm{O}$ at up to $120^{\circ} \mathrm{C}$, a second loss in weight may be detected on the TGA curve at about $400^{\circ} \mathrm{C}$ (Fig. 4). An analysis of the evolved gases indicates the loss of $\mathrm{H}_{2} \mathrm{O}$. No other effect may be detected until $800^{\circ} \mathrm{C}$. The second loss in weight is accompanied on both DTG and DSC curves (Fig. 4) by an endothermic effect, which is due to the breakdown of scawtite to calcite and xonotlite, according to the reaction $\mathrm{Ca}_{7}\left(\mathrm{Si}_{6} \mathrm{O}_{18}\right)\left(\mathrm{CO}_{3}\right) \cdot 2 \mathrm{H}_{2} \mathrm{O}=\mathrm{Ca}_{6} \mathrm{Si}_{6} \mathrm{O}_{17}(\mathrm{OH})_{2}+\mathrm{CaCO}_{3}+$ $\mathrm{H}_{2} \mathrm{O}$.

An XRD analysis of the breakdown products, after cooling of the analyzed powder to $20^{\circ} \mathrm{C}$, confirms the presence, besides tilleyite and rehydrated plombièrite, of xonotlite $[a$ 17.079(11), $b$ 7.336(5), $c$ 6.999(5) $\AA]$ and
TABLE 7. REPRESENTATIVE COMPOSITIONS OF SCAWTITE, CORNET HILL, ROMANIA*

\begin{tabular}{|c|c|c|c|c|c|c|c|}
\hline Sample & 2176 & 2300 & P55 & 2173 & 2233 & 2265 & 2305 \\
\hline Zone & $\mathrm{CH} 2$ & $\mathrm{CH} 2$ & $\mathrm{CH} 3$ & $\mathrm{CH} 3$ & $\mathrm{CH} 3$ & CH 3 & CH 3 \\
\hline $\mathrm{N}^{(1)}$ & 6 & 2 & 3 & 7 & 3 & 2 & 2 \\
\hline $\mathrm{SiO}_{2}$ wt $\%$ & 44.10 & 44.24 & 44.08 & 44.39 & 44.19 & 44.55 & 44.23 \\
\hline $\mathrm{Al}_{2} \mathrm{O}_{3}$ & 0.04 & 0.05 & 0.02 & 0.00 & 0.00 & 0.01 & 0.01 \\
\hline $\mathrm{CaO}$ & 48.10 & 47.99 & 48.19 & 47.84 & 48.21 & 47.72 & 47.96 \\
\hline $\mathrm{MgO}$ & 0.06 & 0.04 & 0.02 & 0.02 & 0.00 & 0.02 & 0.04 \\
\hline $\mathrm{MnO}$ & 0.09 & 0.01 & 0.02 & 0.03 & 0.00 & 0.01 & 0.11 \\
\hline $\mathrm{FeO}^{(2)}$ & 0.02 & 0.06 & 0.06 & 0.06 & 0.00 & 0.00 & 0.00 \\
\hline $\mathrm{Na}_{2} \mathrm{O}$ & 0.00 & 0.00 & 0.03 & 0.02 & 0.00 & 0.03 & 0.04 \\
\hline $\mathrm{CO}_{2}{ }^{(3)}$ & 5.38 & 5.40 & 5.38 & 5.42 & 5.39 & 5.44 & 5.40 \\
\hline $\mathrm{H}_{2} \mathrm{O}$ & 2.21 & 2.21 & 2.20 & 2.22 & 2.21 & 2.22 & 2.21 \\
\hline Total & 100.00 & 100.00 & 100.00 & 100.00 & 100.00 & 100.00 & 100.00 \\
\hline \multicolumn{8}{|c|}{ Number of cations on the basis of $21(\mathrm{O})^{(4)}$} \\
\hline Si apfu & 5.988 & 6.000 & 5.986 & 6.016 & 5.997 & 6.030 & 6.000 \\
\hline Al & 0.007 & 0.008 & 0.003 & 0.000 & 0.000 & 0.002 & 0.002 \\
\hline $\mathrm{Ca}$ & 6.996 & 6.971 & 7.010 & 6.944 & 7.009 & 6.920 & 6.971 \\
\hline Mg & 0.013 & 0,008 & 0.004 & 0.004 & 0.000 & 0.004 & 0.009 \\
\hline $\mathrm{Mn}$ & 0.011 & 0.001 & 0.002 & 0.003 & 0.000 & 0.001 & 0.012 \\
\hline $\mathrm{Fe}^{2-}$ & 0.002 & 0.007 & 0.007 & 0.007 & 0.000 & 0.000 & 0.000 \\
\hline $\mathrm{Na}$ & 0.000 & 0.000 & 0.008 & 0.005 & 0.000 & 0.008 & 0.011 \\
\hline $\mathrm{C}$ & 0.998 & 1.000 & 0.998 & 1.004 & 0.999 & 1.005 & 1.000 \\
\hline
\end{tabular}

* Results of electron-microprobe analyses. (1) Number of point analyses. (2) Total iron expressed as $\mathrm{FeO}$. (3) As calculated for stoichiometry based on the silica content. (4) In the anhydrous part of the formula. apfu: atoms per formula unit.

calcite [ $a$ 4.991(1), $c$ 17.063(2) ̊]. No lines of scawtite may be detected on the X-ray pattern of the cooled powder, which confirms its complete breakdown. Scawtite dehydration took place at higher temperatures than those normally needed for the elimination of the molecular $\mathrm{H}_{2} \mathrm{O}$, which agrees with the presence of the $\mathrm{H}_{2} \mathrm{O}$ molecules coordinated to $\mathrm{Ca}$, as established by Pluth \& Smith (1973) and Zhang et al. (1992).

\section{Xonotlite}

Xonotlite occurs mostly in the $\mathrm{CH} 1$ zone, particularly within the median zone of the gehlenite-wollastonite skarn (zones A2-A3 as defined by Pascal et al. 2001), but also in the CH 2 and $\mathrm{CH} 3$ zones. The mineral is generally associated with wollastonite. At a macroscopic scale, it occurs as white earthy masses; a SEM study of such material shows that the xonotlite crystals are elongate along the $Z$ axis and generally form subparallel intergrowths and sheaf-like aggregates. The individual crystals are typically about $2 \mu \mathrm{m}$ in width and up to $50 \mu \mathrm{m}$ in length. The mean index of refraction, measured on a direction perpendicular to the fiber elongation, varies between 1.578 and 1.583. Except for the positive optical sign, the mineral closely resembles wollastonite. The two minerals are easily distinguishable under the microprobe beam, in view of the stronger cathodoluminescence of xonotlite. Textural relations between xonotlite and wollastonite are complicated, but in most cases, wollastonite seems to be the earlier to 


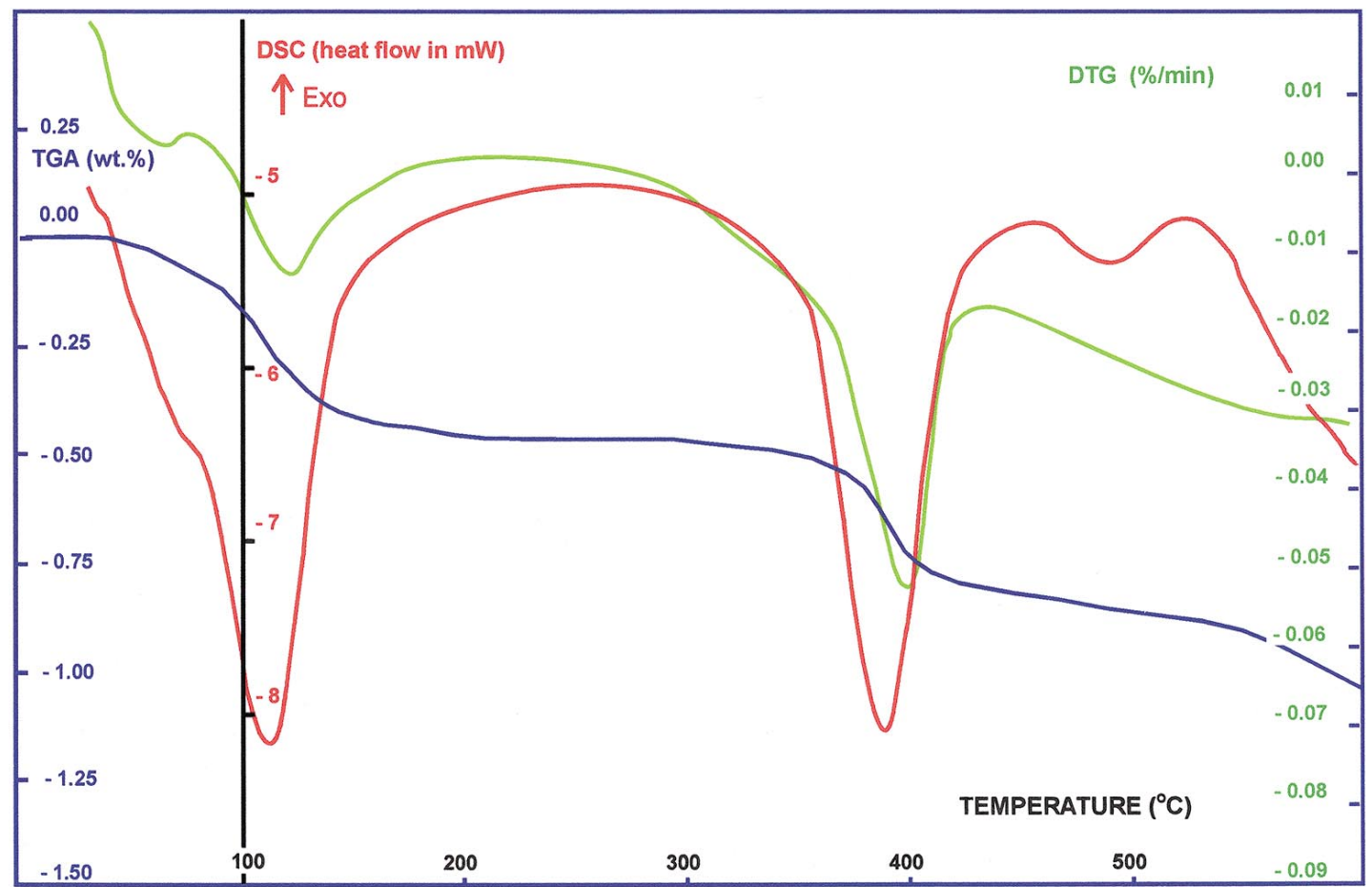

FIG. 4. Thermal curves recorded for a mixture tilleyite - scawtite - plombièrite from Cornet Hill. Differential thermogravimetry (green), differential scanning calorimetry (red) and thermogravimetry (blue).

crystallize. This interpretation is supported by the crystallographic control of the orientation of the xonotlite crystals, which in some cases develop along the rim and the cleavage planes of wollastonite grains. Where xonotlite is well crystallized, it evidently originated by a topotactic reaction from primary wollastonite, during its hydration. The pseudomorphs of xonotlite after wollastonite are commonly oriented perpendicular to the elongation of the wollastonite fibers, defining zones of parting (Fig. 2D).

EMPA analyses of selected samples of xonotlite from $\mathrm{CH} 1$ and $\mathrm{CH} 3$ zones are given in Table 8. Analytical totals are deficient by 2.36 to $4.02 \mathrm{wt} \%$. Structural formulae calculated on the basis of $17(\mathrm{O})$ and 2 $(\mathrm{OH})$ pfu indicate an approach to near-ideal stoichiometry in all cases; the occupancy of the tetrahedral and octahedral sites is very close to $12 \mathrm{apfu}$, whereas the Al-for-Si and the (Fe, Mn, Mg)-for-Ca substitutions are insignificant (Table 8).

Unit-cell parameters of two representative samples are given in Table 2. Except for $c$, they clearly exceed the values given for this mineral by Mamedov \& Belov (1956): $a$ 16.50, $b 7.33, c 7.08 \AA, \beta 90^{\circ}$, but agree better with the values given by Eberhard et al. (1981) for the xonotlite from Heguri, Japan: $a$ 17.03, $b$ 7.356, $c 7.003$
$\AA$ A, $\beta 90.32^{\circ}$ (as calculated for a normal monoclinic cell, derived from the $C 2 / m$ subcell with $b^{\prime}=b / 2$, proposed by these authors).

\section{Hibschite}

During the EMPA investigation of the altered gehlenite from the $\mathrm{CH} 3$ and $\mathrm{CH} 1$ zones, crystals with a garnet-like habit were found to show low totals (90.99 to $92.80 \mathrm{wt} . \%$ ) and strong deficiency in $\mathrm{Si}$, indicating a substantial proportion of a hydrogarnet component. The crystals occur as rounded grains up to $0.1 \mathrm{~mm}$ across within a mass that usually includes allophane, gismondine or thomsonite, xonotlite, wollastonite, and relics of gehlenite. Locally, patches of hydrogarnet armor relics of gehlenite, suggesting that the breakdown of gehlenite may have involved the formation of hydrogarnet. In fact, a narrow rim of gehlenite 15 to $30 \mu \mathrm{m}$ thick having a composition corresponding to a hydrogarnet was found in places, and particularly where gehlenite is altered to allophane. The indices of refraction determined for various grains vary between 1.64 and 1.65 , whereas the unit-cell parameter of a representative sample is given in Table 2 . 
TABLE 8. REPRESENTATIVE COMPOSITIONS OF XONOTLITE, CORNET HILL, ROMANIA*

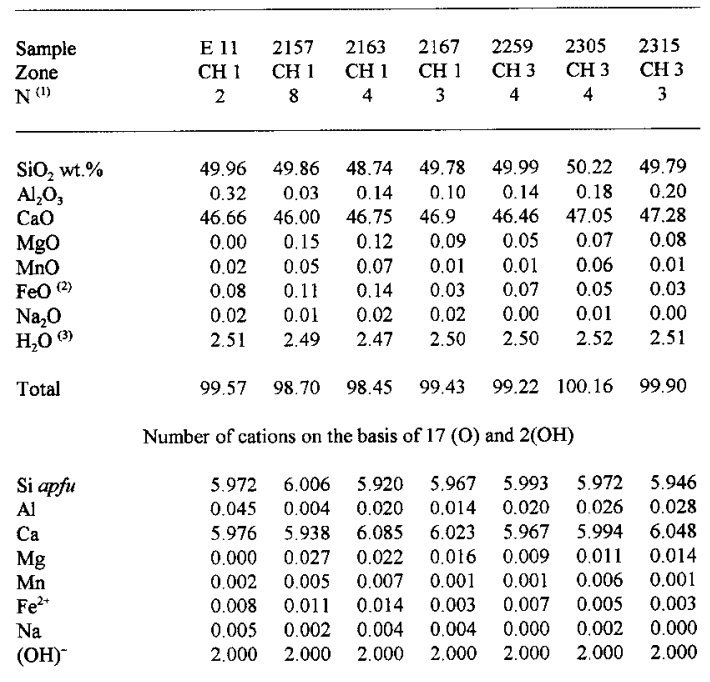

* Results of electron-microprobe analyses. (1) Number of point analyses. (2) Total iron expressed as FeO. (3) As calculated for charge balance. apfu: atoms per formula unit.

Results of EMPA analyses of some grains are given in Table 9 and clearly correspond to a hydrogarnet. The mineral formulae calculated on the basis of 5 cations (excepting $\mathrm{Si}$ ) and $12(\mathrm{O}, \mathrm{OH}, \mathrm{F}, \mathrm{Cl}) p f u$ agrees with the general formula $\mathrm{Ca}_{3} \mathrm{Al}_{2}\left(\mathrm{SiO}_{4}\right)_{3-x}(\mathrm{OH})_{4 x}$, with $x<1.5$, as proposed by Passaglia \& Rinaldi (1984) for hibschite. The sums of the cations others than $\mathrm{H}^{+}$vary between 6.958 and $7.206 \mathrm{apfu}$, which also indicates compositions closer to the grossular end-member of the $\mathrm{Ca}_{3} \mathrm{Al}_{2}\left(\mathrm{SiO}_{4}\right)_{3}$ $-\mathrm{Ca}_{3} \mathrm{Al}_{2}(\mathrm{OH})_{12}$ solid-solution series.

\section{Gismondine}

Gismondine was identified in the $\mathrm{CH} 1$ zone, near the contact with the intrusive rock. The mineral occurs as fan-shaped aggregates of lath-like crystals up to 0.5 $\mathrm{mm}$ in length, disposed along fractures that affect the gehlenite + wollastonite mass (Fig. 2E). Under crossed nicols, single crystals are length-fast, indicating that they are elongate in the $Z$-axis direction. The optic sign is negative. The unit-cell parameters obtained for a representative sample (Table 2) differ slightly from those reported for stoichiometric gismondine by Fischer \& Kuzel (1958) (a 10.02, b 10.62, c 9.84 $\left.\AA, \beta 92^{\circ} 25^{\prime}\right)$ or by Bauer \& Baur (1998) [a 10.018(1), $b$ 10.620(1), $c$ 9.830(1) $\AA, \beta 92.35(1)^{\circ}$ ], in good agreement with the (low) content of $\mathrm{Na}$ revealed by chemical analysis, which must increase the $a$ and $c$ parameters and decrease $b$ and $\beta$ (Bauer \& Baur 1998); except for the constancy of $a$, this is respected in our sample.
TABLE 9. REPRESENTATIVE COMPOSITIONS OF HIBSCHTE, CORNET HLL, ROMANIA*

\begin{tabular}{|c|c|c|c|c|c|}
\hline Sample & 2161 & 2167 & 2234 & P57 & P55 \\
\hline Zone & $\mathrm{CH} 1$ & $\mathrm{CH} 1$ & $\mathrm{CH} 1$ & $\mathrm{CH} 1$ & $\mathrm{CH} 3$ \\
\hline$N^{(1)}$ & 3 & 3 & 2 & 2 & 2 \\
\hline $\mathrm{SiO}_{2}$ wt $\%$ & 27.57 & 29.84 & 30.05 & 28.73 & 30.40 \\
\hline $\mathrm{Al}_{2} \mathrm{O}_{3}$ & 21.33 & 21.11 & 19.35 & 21.62 & 19.70 \\
\hline $\mathrm{Fe}_{2} \mathrm{O}_{3}(2)$ & 0.82 & 0.61 & 2.03 & 0.43 & 1.06 \\
\hline $\mathrm{CaO}$ & 36.36 & 35.23 & 36.99 & 39.66 & 35.18 \\
\hline $\mathrm{MgO}$ & 3.81 & 4.16 & 4.25 & 1.61 & 4.79 \\
\hline $\mathrm{MnO}$ & 0.00 & 0.04 & 0.01 & 0.00 & 0.06 \\
\hline $\mathrm{H}_{2} \mathrm{O}^{(3)}$ & 9.00 & 7.40 & 7.82 & 8.58 & 7.09 \\
\hline F & 0.32 & 0.00 & 0,00 & 0.00 & 0.00 \\
\hline $\mathrm{Cl}$ & 0.00 & 0.00 & 0.16 & 0.00 & 0.00 \\
\hline $\mathrm{O}=\mathrm{F}, \mathrm{Cl}$ & -0.14 & -0.00 & -0.04 & -0.00 & -0.00 \\
\hline Total & 99.07 & 98.39 & 100.62 & 100.63 & 98.28 \\
\hline
\end{tabular}

Number of ions on the basis of $5\left(\mathrm{Ca}+\mathrm{Mg}+\mathrm{Mn}+\mathrm{Al}+\mathrm{Fe}^{3+}\right)$ and $12(\mathrm{O}, \mathrm{OH}, \mathrm{F}, \mathrm{Cl})$

$\begin{array}{llllll}\text { Si apfu } & 1.958 & 2.152 & 2.137 & 2.032 & 2.206 \\ \mathrm{Al} & 1.785 & 1.795 & 1.622 & 1.802 & 1.685 \\ \mathrm{Fe}^{3+} & 0.044 & 0.033 & 0.109 & 0.023 & 0.058 \\ \mathrm{Ca} & 2.767 & 2.723 & 2.818 & 3.005 & 2.735 \\ \mathrm{Mg} & 0.404 & 0.447 & 0.450 & 0.170 & 0.518 \\ \mathrm{Mn} & 0.000 & 0.002 & 0.001 & 0.000 & 0.004 \\ (\mathrm{OH})^{-} & 4.268 & 3.564 & 3.702 & 4.047 & 3.433 \\ \mathrm{~F} & 0.071 & 0.000 & 0.000 & 0.000 & 0.000 \\ \mathrm{Cl} & 0.000 & 0.000 & 0.019 & 0.000 & 0.000\end{array}$

* Results of electron-microprobe analyses. (1) Number of point analyses. (2) Total iron expressed as $\mathrm{Fe}_{2} \mathrm{O}_{3}$. (3) The proportion of $\mathrm{H}_{2} \mathrm{O}$ was calculated to satisfy charge balance. apfu: atoms per formula unit

Results of an EMP analysis of a selected sample of gismondine from Cornet Hill is listed in Table 10 (anal. 1). The $\mathrm{H}_{2} \mathrm{O}$ content was calculated with an assumption of stoichiometry, following the general formula $\mathrm{Ca}_{2} \mathrm{Al}_{4} \mathrm{Si}_{4} \mathrm{O}_{16} \cdot 9 \mathrm{H}_{2} \mathrm{O}$, as derived from that proposed by Vezzalini \& Oberti (1984). The number of ions was calculated on the basis of $4(\mathrm{Al}+\mathrm{Si}) p f u$. Gismondine from Cornet Hill contains 93.4 mol.\% of its end-member component, the remainder being essentially complemented by the "gismondine-Na" component, ideally $\mathrm{Na}_{4} \mathrm{Al}_{4} \mathrm{Si}_{4} \mathrm{O}_{16} \cdot 9 \mathrm{H}_{2} \mathrm{O}$.

\section{Thomsonite}

Thomsonite was found more frequently than gismondine, in both $\mathrm{CH} 1$ and $\mathrm{CH} 3$ zones. The mineral is easy to identify because of its classical optical properties (straight extinction, low birefringence, $+2 V \approx 55^{\circ}$ ) and habit. It occurs as fan- or rosette-like aggregates of platy crystals up to $0.5 \mathrm{~mm}$ in length, generally disposed on the fractures affecting the gehlenite mass. Representative results of EMP analyses are given in Table 10 (anal. 2-4). Formulae were calculated on the basis of 5 $(\mathrm{Al}+\mathrm{Si}) a p f u$, whereas the proportion of $\mathrm{H}_{2} \mathrm{O}$ was calculated on the basis of $6 \mathrm{H}_{2} \mathrm{O} p f u$, accepting the formula recommended for this mineral by Coombs et al. (1997): $\mathrm{Ca}_{2} \mathrm{Na}\left[\mathrm{Al}_{5} \mathrm{Si}_{5} \mathrm{O}_{20}\right] \cdot 6 \mathrm{H}_{2} \mathrm{O}$. The Na contents of individual samples vary over a broad range, from 3.16 to $3.71 \mathrm{wt} \%$ 
TABLE 10. REPRESENTATIVE COMPOSITIONS OF GISMONDINE AND THOMSONITE, CORNET HILL, ROMANIA*

\begin{tabular}{|c|c|c|c|c|}
\hline Sample & P79 & 2161 & 2163 & P55 \\
\hline Zone & $\mathrm{CH} 1$ & $\mathrm{CH} 1$ & $\mathrm{CH} \mathrm{l}$ & CH 3 \\
\hline $\mathrm{N}^{(1)}$ & 2 & 4 & 4 & 3 \\
\hline $\mathrm{SiO}_{2}$ wt. $\%$ & 34.15 & 37.86 & 37.58 & 37.66 \\
\hline $\mathrm{Al}_{2} \mathrm{O}_{3}$ & 29.02 & 30.83 & 30.49 & 30.38 \\
\hline $\mathrm{CaO}$ & 15.72 & 13.12 & 13.59 & 13.73 \\
\hline $\mathrm{MgO}$ & 0.10 & 0.92 & 0.28 & 0.04 \\
\hline $\mathrm{MnO}$ & 0.00 & 0.00 & 0.02 & 0.01 \\
\hline $\mathrm{FeO}^{(2)}$ & 0.01 & 0.42 & 0.08 & 0.07 \\
\hline $\mathrm{Na}_{2} \mathrm{O}$ & 0.12 & 3.15 & 3.59 & 3.66 \\
\hline $\mathrm{K}_{2} \mathrm{O}$ & 0.01 & 0.00 & 0.01 & 0.00 \\
\hline $\mathrm{H}_{2} \mathrm{O}^{(3)}$ & 23.05 & 13.35 & 13.22 & 13.22 \\
\hline Total & 102.18 & 99.65 & 98.86 & 98.77 \\
\hline \multicolumn{5}{|c|}{ Number of cations on the basis of $X^{(4)}$ cations } \\
\hline Si apfu & 3.997 & 5,103 & 5.112 & 5.126 \\
\hline $\mathrm{Al}$ & 4.003 & 4.897 & 4.888 & 4.874 \\
\hline $\mathrm{Ca}$ & 1.971 & 1.895 & 1.981 & 2.002 \\
\hline $\mathrm{Mg}$ & 0.017 & 0.185 & 0.057 & 0.008 \\
\hline $\mathrm{Mn}$ & 0.000 & 0.000 & 0.002 & 0.001 \\
\hline $\mathrm{Fe}^{2+}$ & 0.001 & 0.047 & 0.009 & 0.008 \\
\hline $\mathrm{Na}$ & 0.027 & 0.823 & 0.947 & 0.966 \\
\hline $\mathrm{K}$ & 0.001 & 0.000 & 0.002 & 0.000 \\
\hline
\end{tabular}

* Results of electron-microprobe analyses. (1) Number of point analyses. (2) Total iron expressed as $\mathrm{FeO}$. (3) $\mathrm{H}_{2} \mathrm{O}^{-}$calculated for stoichiometry. (4) $X=8(\mathrm{Si}+\mathrm{Al})$ in gismondine, and $10(\mathrm{Si}+\mathrm{Al})$ in thomsonite. Column 1 : gismondine, columns 2-4: thomsonite. apftr: atoms per formula unit.

$\mathrm{Na}_{2} \mathrm{O}$. In contrast, the $\mathrm{K}$ contents are very low (up to 0.002 apfu), which agrees well with the low potassium contents found in this mineral by Ross et al. (1992). The occupancies of the tetrahedral sites by $\mathrm{Si}\left[T_{\mathrm{Si}}=\mathrm{Si} /(\mathrm{Si}+\right.$ $\mathrm{Al})$ ] vary between 0.510 and 0.513 , being in the range found for thomsonite by Coombs et al. (1997): $0.50<$ $T_{\mathrm{Si}}<0.56$

\section{Plombièrite}

The results of the thermogravimetric analysis (Fig. 4) indicate that the weight loss at $\sim 120^{\circ} \mathrm{C}$, due to a loss of $\mathrm{H}_{2} \mathrm{O}$, is 0.37 wt.\%. As tilleyite is anhydrous and scawtite dehydrates at higher temperatures, the sample must also contain small amounts of other hydrous impurities, which are not resolvable under the binocular microscope. An XRD study of the initial material indicates that this phase is plombièrite. In fact, a $14-\AA$ diffraction peak may be systematically observed in most of the samples containing scawtite. In conjunction with optical observations and back-scattered electron imaging, this evidence indicates the presence of plombièrite as an alteration product on scawtite.

Fractures hosting scawtite and plombièrite occur irregularly through the tilleyite mass but seem to be more common in and adjacent to water-laden faults that traverse the outcrops. Plombièrite is the most abundant of these fracture fillings and commonly lines fractures in the tilleyite and, in some cases, in the wollastonite masses, with crusts of needle-like crystals grouped in bunches (Fig. 2F) and fan-like or star-shaped aggregates. In the $\mathrm{CH} 3$ zone, a thin seam of scawtite invariably separates tilleyite from plombièrite. Individual crystals are usually elongate along the $Z$ axis and invariably are subparallel and intergrown to form aggregates. The crystals are very small, seldom exceeding 0.1 $\mathrm{mm}$ in length and $5 \mu \mathrm{m}$ in thick, which precludes a good optical characterization. However, it may be inferred that the mineral must be biaxial positive. Bunches of crystals are length-slow with low birefringence; the mineral seems to have parallel extinction.

Upon complete dehydration of an impure material containing tilleyite, scawtite and plombièrite (sample $\mathrm{P}$ 55) by heating at $800^{\circ} \mathrm{C}$ in nitrogen, the $14-\AA$ spacing disappeared. Rehydration of the heated material after cooling in air recomposes plombièrite $[a$ 5.625(4), $b$

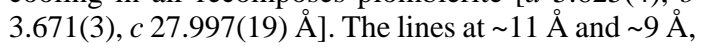
characteristic of tobermorite polytypes, which must occur during the heating (Hamid Rahman \& Beyrau 1988), were not observed in the cooled product.

Representative results of electron-microprobe analyses of plombièrite and the atomic contents on the basis of 11 cations (others than $\mathrm{H}$ ) and $18(\mathrm{O})$ per anhydrous formula unit are given in Table 11 (anal. 1-4). The proportion of $\mathrm{H}_{2} \mathrm{O}$ was calculated on the basis of stoichiometry, using the structural formula tentatively accepted by Mandarino (1999): $\mathrm{Ca}_{5} \mathrm{H}_{2} \mathrm{Si}_{6} \mathrm{O}_{18} \cdot 6 \mathrm{H}_{2} \mathrm{O}$. The structural formulae (Table 11) are remarkably constant. The $\mathrm{Mn}, \mathrm{Fe}, \mathrm{Mg}, \mathrm{Na}$ and $\mathrm{K}$ contents are negligible (only up to $0.79 \%$ from the Ca sites are occupied by cations others than $\mathrm{Ca}$ ), and the proportion of ${ }^{\mathrm{IV}} \mathrm{Al}$ is minor.

\section{Tobermorite}

A $11-\AA$ phase, identified as tobermorite, most commonly occurs as bunches, sheaf-like or radiating aggregates of acicular or fibrous crystals up to $50 \mu \mathrm{m}$ long and $2 \mu \mathrm{m}$ wide (Fig. 2F). It is similar in habit to the tobermorite from Ballycraigy, Northern Ireland, described by McConnell (1955). The spatial relationship between plombièrite and tobermorite suggests that the two minerals have cocrystallized or tobermorite preceded plombièrite. Fibers of tobermorite are too small to permit a good optical characterization. The mean index of refraction is $1.560(5)$, which is slightly larger than that measured by Bentor et al. (1963) for tobermorite from the "Mottled Zone" complex, Israel $(\overline{\mathrm{n}}=\beta=1.552)$.

The EMPA data for four selected samples of tobermorite, in which this mineral was previously identified by XRD, are given in Table 11 (anal. 5-8). As the composition of tobermorite remains ill-defined owing to the lack of coarse-grained and pure material for study (e.g., Mitsuda \& Taylor 1978), the number of ions in Table 11 was calculated assuming $(\mathrm{Si}+\mathrm{Al})=12$ and 36 $(\mathrm{O}, \mathrm{OH}, \mathrm{F}) p f u$, accepting a formula derived from those proposed by Hamid (1981) and Hamid Rahman \& Beyrau (1988): $\mathrm{Ca}_{2.25}\left[\mathrm{Si}_{3} \mathrm{O}_{7.5}(\mathrm{OH})_{1.5}\right] \cdot \mathrm{H}_{2} \mathrm{O}$ and $\mathrm{Ca}_{5}\left[\mathrm{Si}_{6}\right.$ 
TABLE 11. REPRESENTATIVE COMPOSITIONS OF PLOMBIÉRITE, TOBERMORITE AND RIVERSIDEITE, CORNET HILL, ROMANIA*

\begin{tabular}{|c|c|c|c|c|c|c|c|c|c|}
\hline $\begin{array}{l}\text { Sample } \\
\text { Zone }\end{array}$ & $\begin{array}{l}2162 \\
\mathrm{CH} 3\end{array}$ & $\begin{array}{l}2170 \mathrm{~A} \\
\mathrm{CH} 3\end{array}$ & $\begin{array}{l}2170 \mathrm{~B} \\
\mathrm{CH} 3\end{array}$ & $\begin{array}{l}2175 \\
\mathrm{CH} 3\end{array}$ & $\begin{array}{l}2163 \\
\mathrm{CH} 1\end{array}$ & $\begin{array}{l}2223 \\
\mathrm{CH} 3\end{array}$ & $\begin{array}{l}2315 \\
\mathrm{CH} 3\end{array}$ & $\begin{array}{l}\text { P } 55 \\
\mathrm{CH} 3\end{array}$ & $\begin{array}{l}2173 \\
\mathrm{CH} 3\end{array}$ \\
\hline $\mathrm{N}^{(1)}$ & 3 & 8 & 7 & 6 & 3 & 3 & 2 & 2 & 3 \\
\hline $\mathrm{SiO}_{2}$ wt. $\%$ & 46.71 & 46.97 & 47.65 & 47.84 & 47.68 & 51.25 & 53.03 & 52.65 & 51.70 \\
\hline $\mathrm{Al}_{2} \mathrm{O}_{3}$ & 0.13 & 0.76 & 0.45 & 0.01 & 6.07 & 0.04 & 0.20 & 0.05 & 0.29 \\
\hline $\mathrm{CaO}$ & 36.09 & 35.77 & 36.54 & 36.75 & 36.00 & 37.40 & 36.78 & 35.31 & 39.87 \\
\hline $\mathrm{MgO}$ & 0.01 & 0.01 & 0.01 & 0.06 & 0.27 & 0.02 & 0.08 & 0.09 & 0.04 \\
\hline $\mathrm{MnO}$ & 0.00 & 0.02 & 0.04 & 0.03 & 0.03 & 0.00 & 0.08 & 0.01 & 0.01 \\
\hline $\mathrm{FeO}^{(2)}$ & 0.04 & 0.10 & 0.13 & 0.03 & 0.02 & 0.04 & 0.10 & 0.02 & 0.02 \\
\hline $\mathrm{Na}_{2} \mathrm{O}$ & 0.00 & 0.02 & 0.02 & 0.04 & 0.00 & 0.06 & 0.00 & 0.08 & 0.03 \\
\hline $\mathrm{K}_{2} \mathrm{O}$ & 0.00 & 0.08 & 0.09 & 0.04 & 0.18 & 0.01 & 0.01 & 0.12 & 0.04 \\
\hline $\mathrm{H}_{2} \mathrm{O}^{+(3)}$ & 2.30 & 2.29 & 2.38 & 2.36 & 5.63 & 3.38 & 4.11 & 4.38 & 2.81 \\
\hline $\mathrm{F}$ & 0.00 & 0.00 & 0.00 & 0.00 & 0.31 & 0.00 & 0.00 & 0.00 & 0.00 \\
\hline $\mathrm{H}_{2} \mathrm{O}^{-(4)}$ & 13.98 & 14.10 & 14.34 & 14.28 & 5.47 & 5.13 & 5.33 & 5.27 & 5.21 \\
\hline $\mathrm{O}=\mathrm{F}$ & -0.00 & -0.00 & -0.00 & -0.00 & -0.13 & -0.00 & -0.00 & -0.00 & -0.00 \\
\hline Total & 99.261 & 100.12 & 101.6 & 101.4 & 101.53 & 97.33 & 99.72 & 97,98 & 99.93 \\
\hline \multicolumn{10}{|c|}{ Number of cations on the basis of $X^{(5)}$ ions } \\
\hline Si apfu & 6.004 & 5.977 & 5.980 & 6.015 & 10.434 & 11.989 & 11.947 & 11.987 & 5.961 \\
\hline Al & 0.020 & 0.114 & 0.067 & 0.001 & 1.566 & 0.011 & 0.053 & 0.013 & 0.039 \\
\hline $\mathrm{Ca}$ & 4.970 & 4.877 & 4.914 & 4.951 & 8.441 & 9.374 & 8.878 & 8.613 & 4.925 \\
\hline $\mathrm{Mg}$ & 0.002 & $2 \quad 0.002$ & 0.002 & 0.011 & 0.088 & 0.007 & 0.027 & 0.031 & 0.007 \\
\hline Mn & 0.000 & 0.002 & 0,004 & 0.003 & 0.006 & 0.000 & 0.015 & 0.002 & 0.001 \\
\hline $\mathrm{Fe}^{2+}$ & 0.004 & $4 \quad 0.011$ & 0.014 & 0.003 & 0.004 & 0.008 & 0.019 & 0.004 & 0.002 \\
\hline $\mathrm{Na}$ & 0.000 & 0.005 & 0.005 & 0.010 & 0.000 & 0.027 & 0.000 & 0.035 & 0.007 \\
\hline $\mathrm{K}$ & 0.000 & 0.012 & 0.014 & 0.006 & 0.049 & 0.003 & 0.003 & 0.035 & 0.006 \\
\hline $\mathbf{H}$ & 1.972 & 21.949 & 1.992 & 1.985 & 8.223 & 5.203 & 6.172 & 6.643 & 2.156 \\
\hline $\mathbf{F}$ & 0.000 & 0.000 & 0.000 & 0.000 & 0.216 & 0.000 & 0.000 & 0.000 & 0.000 \\
\hline
\end{tabular}

* Results of electron-microprobe analyses. (1) Number of point analyses. (2) Total iron expressed as $\mathrm{FeO}$. (3) $\mathrm{H}_{2} \mathrm{O}^{+}$calculated for charge balance. (4) $\mathrm{H}_{3} \mathrm{O}^{-}$calculated for stoichiometry. (5) $X=11$ cations (others than $\mathrm{H}$ ) and $18(\mathrm{O})$ for plombièrite; $X$ $=12(\mathrm{Si}+\mathrm{Al})$ and $36(\mathrm{O}, \mathrm{OH}, \mathrm{F})$ for tobermorite; $X=6(\mathrm{Si}+\mathrm{Al})$ and $18(\mathrm{O}, \mathrm{OH})$ for riversideite Columns 1-4: plombièrite, 5-8: tobermorite, 9: riversideite. apfu: atoms per formula unit.

$\left.\mathrm{O}_{16}(\mathrm{OH})_{2}\right] \cdot 2 \mathrm{H}_{2} \mathrm{O}$, respectively. The proportion of $\mathrm{H}_{2} \mathrm{O}$ was calculated by stoichiometry on the basis of the crystal structure proposed by Hamid (1981), with $4 \mathrm{H}_{2} \mathrm{O}$ molecules for $12(\mathrm{Si}+\mathrm{Al}) p f u$. Some low totals agree, however, with a higher degree of hydration, as suggested by McConnell (1954) or Kusachi et al. (1980). Tobermorite in the $\mathrm{CH} 3$ zone (anal. 6-8, Table 11) is Al-depleted, the Al-for-Si substitution reaching only up to $0.44 \%$ in the tetrahedral sites. Mitsuda \& Taylor (1978) mentioned a similar behavior only in tobermorite from Ballycraigy. The extent of replacement of $\mathrm{Ca}$ by $\mathrm{Mn}, \mathrm{Mg}, \mathrm{Fe}, \mathrm{Na}$ and $\mathrm{K}$ is very limited, which agrees with the trend reported for plombièrite.

In all XRD patterns, the tobermorite from the $\mathrm{CH} 3$ zone was found to be admixed with plombièrite, which has some lines coincident with or very close to those of tobermorite (e.g., those near 5.50, 3.50, 3.30, 3.08, 2.82, $2.08,2.00,1.84,1.82,1.67,1.57$ and $1.51 \AA$ ). In all but a few cases, the tobermorite and plombièrite lines could be resolved by using slow scans. In all cases, the tobermorite lines may be successfully indexed on an orthorhombic cell. The strong orthorhombic subcell proposed by Hamid (1981) $\left(a^{\prime}=a / 2, b^{\prime}=b / 2\right)$ was used as basis for the refinement of the unit-cell parameters (Table 2). These differ in detail by those given for the orthorhombic tobermorite from Fuka by Henmi \& Kusachi (1989) [a 11.233(3), b 7.372(3), c 22.56(1) ̊]], with $a$ and $c$ larger and $b$ approximately matched.

A second textural variety of tobermorite occurs on thin veins in the gehlenite-bearing skarns from the $\mathrm{CH}$ 1 zone, together with gismondine (Fig. 2G). Its identity or polymorph could not be verified by XRD because of scarcity of material, but the 11- $\AA$ line was recognized in a hand-picked separate. This tobermorite consists of very fine fibers and forms mainly along cracks in gismondine, at a scale near the resolution of the electron beam. Its crystallization clearly postdates the local transformation of gehlenite to zeolites. The mineral, which is homogeneous on back-scattered electron images, may be analyzed only in relatively coarser, fasciculate bunches of crystals, but even in these, some overlaps with relics of gismondine are unavoidable. However, recalculation of the resulting data surprisingly yields satisfactory compositions (anal. 5, Table 11). The composition indicates a fluorine-bearing Al-rich variety of tobermorite.

\section{Riversideite}

A 9-Å phase was recognized in many separates containing plombièrite and was subsequently identified as riversideite. Dendritic, star-shaped, subparallel or irregular intergrowths of this mineral fill or line some of the fissures that affect the tilleyite mass in the $\mathrm{CH} 3$ zone (Fig. 2H). Individual fibers up to $50 \mu \mathrm{m}$ in length are easily confused with the intergrown plombièrite. As well as tobermorite, riversideite apparently postdates scawtite and predates plombièrite. A mean index of refraction $\bar{n}$ measured at the periphery of a composite aggregate of riversideite and plombièrite is 1.600(5), which agrees perfectly with the $\bar{n}$ value of 1.602 that may be deduced from the measurements made on riversideite from Ballycraigy by McConnell (1954). The unit-cell parameters of two representative samples are given in Table 2.

The presence of cryptocrystalline phases, poor diffractors of $X$-rays, and of intergrown plombièrite may influence the analysis of riversideite, whose composition varies quite importantly. For this reason, only one chemical composition was selected to be listed in Table 11 (anal. 9). As the true stoichiometry of the mineral is still unknown, the formula accepted by Mandarino (1999), i.e., $\mathrm{Ca}_{5} \mathrm{Si}_{6} \mathrm{O}_{16}(\mathrm{OH})_{2} \cdot 2 \mathrm{H}_{2} \mathrm{O}$ was used as basis for the $\mathrm{H}_{2} \mathrm{O}$ calculation. The formula was calculated by normalization to $6(\mathrm{Si}+\mathrm{Al})$ and $18(\mathrm{O}, \mathrm{OH}) p f u$, then $\mathrm{H}_{2} \mathrm{O}^{+}$was calculated from charge balance and $\mathrm{H}_{2} \mathrm{O}^{-}$for stoichiometry. As in the cases of tobermorite and plombièrite in the $\mathrm{CH} 3$ zone, the extent of $\mathrm{Al}$-for-Si and (Mn, $\mathrm{Mg}, \mathrm{Fe}, \mathrm{K}, \mathrm{Na}$ )-for-Ca substitutions is minor (Table 11). 


\section{Aragonite}

Aragonite forms small rosette-like aggregates of long prismatic crystals $<0.5 \mathrm{~mm}$ in size disposed on fissures that cross-cut the spurrite and tilleyite masses in the $\mathrm{CH} 2$ and $\mathrm{CH} 3$ zones, respectively. Relatively late crystallization of this carbonate seems to be very likely, since it clearly postdates tilleyite. In fact, results of the XRD study correlated with morphological aspects show that two generations of late carbonates coexist on these fractures: earlier aragonite is progressively replaced by fine radiating aggregates of later calcite. The unit-cell parameters of two representative samples are listed in Table 2. They differ in detail from those given for stoichiometric aragonite by Dickens \& Bowen (1971), i.e., $a$ 4.9598(5), b 7.9641(9), c 5.7379(6) $\AA$, which reflects differences in composition. The chemical composition of one of the samples (2176), taken as mean result of six point analyses on different crystals, is (in wt.\%): $55.99 \% \mathrm{CaO}, 0.01 \% \mathrm{MnO}, 0.01 \% \mathrm{MgO}, 0.02 \% \mathrm{FeO}$, with $43.95 \% \mathrm{CO}_{2}$ (as calculated for stoichiometry). Ba and $\mathrm{Sr}$ were sought, but not detected. The following formula may be deduced from the mean composition: $\mathrm{Ca}_{1.998} \mathrm{Mg}_{0.001} \mathrm{Fe}^{2+}{ }_{0.001}\left(\mathrm{CO}_{3}\right)_{2}$.

\section{Calcite}

Secondary, residual or recrystallized calcite occurs commonly on the fissures affecting the masses of tilleyite and spurrite; it is interstitial to, fills fractures in and penetrates on an extremely fine scale along the cleavages and crystal boundaries of the wollastonite crystals. Some of the samples have a fibrous appearance and were suspected to represent a pseudomorph after aragonite. Quick XRD tests after very careful grinding showed, however, that only calcite is present in these samples. The unit-cell parameters of three representative samples are given in Table 2. The average composition, obtained as the average of 13 samples, is (in wt. \%): 55.95(7)\% $\mathrm{CaO}, 0.01(2) \% \mathrm{MnO}, 0.02(3) \%$ $\mathrm{MgO}, 0.05(6) \% \mathrm{FeO}$, and 43.97(1)\% $\mathrm{CO}_{2}$ (as calculated from stoichiometry). The standard errors (given into brackets) reflect the chemical homogeneity. In all cases, the mineral has a composition close to that of the end member, containing up to $0.25 \mathrm{~mol} \%$ magnesite, 0.35 mol.\% siderite and 0.10 mol.\% rhodochrosite components in solid solution.

\section{Portlandite}

Portlandite occurs as fine platy crystals in masses representing the alteration product of wollastonite from the $\mathrm{CH} 1$ zone. Flakes of portlandite up to $30 \mu \mathrm{m}$ across are oriented randomly or in arrays subparallel to the parting zones defined by the xonotlite pseudomorphs after wollastonite. These flakes occur in the water-laden fissures that cross the xonotlite + wollastonite mass. Portlandite also may occur sporadically as a coating on the surface of the spurrite-bearing skarn in the $\mathrm{CH} 2$ zone. The average chemical composition, given as the mean result of seven random point-analyses taken on various crystals on the same thin section (sample 2170) is (in wt.\%): $85.74 \% \mathrm{CaO}, 0.27 \% \mathrm{MnO}, 0.12 \% \mathrm{FeO}$, $0.09 \% \mathrm{~F}$ and $13.78 \% \mathrm{H}_{2} \mathrm{O}$ (as calculated from stoichiometry). The structural formula calculated on the basis 2 (OH,F) pfu is: $\left(\mathrm{Ca}_{1.993} \mathrm{Mn}_{0.005} \mathrm{Fe}^{2+}{ }_{0.002}\right)\left(\mathrm{OH}_{1.994} \mathrm{~F}_{0.006}\right)$. The cell parameters obtained for the same sample are given in Table 2. Small differences with the cell parameters given for synthetic portlandite [i.e., a 3.5899(4) and $c 4.916(3) \AA$, PDF 44-1481] are explained by the F-for- $\mathrm{OH}$ and (Fe, Mn)-for-Ca substitutions.

\section{Allophane}

All the Al-bearing silicates, and particularly gehlenite, are partly replaced along fine fissures that affects their masses by porous or gel-like aggregates containing $\mathrm{Al}$ and $\mathrm{Si}$ as main elements. XRD patterns show that most of these alteration products are amorphous. The two distinctive broad humps centered around 2.25 and $3.30 \AA$, respectively, are consistent with the presence of allophane (Yoshinaga \& Aomine 1962). Its very late formation is indicated by the replacement of both hibschite and gismondine by allophane; these minerals may be found as relics in the mass of allophane. Also, vesuvianite at the periphery of the altered gehlenite may be cross-cut by veins containing allophane. The material has a mean index of refraction that varies from sample to sample between 1.475 and 1.483 , possibly because of a variable degree of hydration.

\section{Discussion AND Conclusions}

On the basis of textural relationships among the various species, it is possible to attempt to determine the history of crystallization of the main phases in the skarn at Cornet Hill. A series of mineral associations that crystallized during the metasomatic events is followed by three subsequent stages of hydrothermal alteration and weathering.

The assemblages of metasomatic minerals may be ascribed to two different groups of parageneses. A first group corresponds to early metasomatic events. Among the earliest observable associations in the innermost skarn zone, a fine-grained aggregate of fibrous wollastonite and grossular is formed, with remnants of textures showing an endoskarn origin; the outer part of the inner skarn zone includes, besides gehlenite, perovskite, hydroxylellestadite, grossular and even spurrite. In both zones, broadly corresponding to $\mathrm{CH} 1$, the temperature has been high enough to stabilize the gehlenite-wollastonite association. In the outer part of the zoned skarn, corresponding to the $\mathrm{CH} 3$ and $\mathrm{CH} 2$ zones, the early association includes tilleyite, spurrite, gehlenite and grossular. 
Comparatively early reworking of this zonation developed part of the vesuvianite, diopside, titanian andradite and monticellite. Textures such as the growth of vesuvianite or pyroxene on the fractures of tilleyite spurrite - gehlenite assemblages, and the growth of vesuvianite on gehlenite and of titanian andradite on perovskite, indicate that the primary assemblages were locally overprinted by secondary ones, defining a subsequent episode of metasomatism and, consequently, a late metasomatic paragenesis.

Vesuvianite developed as zoned products of alteration of gehlenite formed earlier. At a later stage, but apparently during the same early hydrothermal event, hydrated $\mathrm{Ca}$ silicates appeared as hydrothermal alterations of the high-temperature phases; they include scawtite, hibschite and xonotlite + calcite assemblages. The second stage of hydrothermal alteration essentially resulted in the deposition of aragonite, zeolites and calcite on fissures affecting all the previous phases, and in the alteration of scawtite to form riversideite, calcite, and tobermorite, and of gismondine, thomsonite and xonotlite to form tobermorite.

Weathering overprints all the previous assemblages. Within the weathering paragenesis, the most common supergene silicate is plombièrite (which essentially replaces scawtite, riversideite, tobermorite and xonotlite) and allophane (which replaces both primary phases, e.g., gehlenite, vesuvianite and secondary ones, e.g., hibschite and zeolites). Portlandite also was identified as a product of weathering, but it seems highly unstable upon exposure to the atmosphere. Textural evidence, supported by the chemical composition of individual phases, suggests the presence, as a product of weathering, of a number of secondary $\mathrm{CaO}-\mathrm{SiO}_{2}-\mathrm{H}_{2} \mathrm{O}$ gels identical with those identified by Sabine \& Young (1975) at Carneal and described as "allophane".

The paragenetic sequence among the late hydrothermal mineral species is not particularly well defined; many seem to be contemporaneous or to have been influenced by weathering. It is noteworthy, however, that some successions, i.e., riversideite - plombièrite or tobermorite - plombièrite, may be well documented. As established by Hamid Rahman \& Beyrau (1988), these sequences of crystallization may express a decrease in temperature, which agrees perfectly with the succession from hydrothermal activity to weathering. Note also that observations on the hydrated calcium silicates and hydrothermal studies in the system $\mathrm{CaO}-\mathrm{SiO}_{2}-\mathrm{H}_{2} \mathrm{O}$ (e.g., McConnell 1954, Harker 1964) prove that plombièrite ("the $14 \AA$ tobermorite") is the more stable "tobermoritic" phase at low temperatures.

In our XRD study of tobermorite- and plombièritebearing samples (e.g., sample 2315), some other reflections attributable to (002) spacings of calcium silicate hydrates i.e., those at $\sim 12.5 \AA$ (the "C-S-H I phase" according to Taylor 1997) and $10.2 \AA$ (the $10 \AA$ tobermorite of Kusachi et al. 1980) were recognized.
Their study is in progress, and they will be subject of a future communication.

\section{ACKNOWLEDGEMENTS}

The Rhône-Alpes Region is gratefully acknowledged for partially financing the research work by providing a TEMPRA grant to the senior author. Ş.M. also acknowledges support from the National Agency for Science, Technology and Innovation (Romania) through grant 6176/2000. Thanks are due to Messrs. Hubert Rémy, Michel Fialin and to Mrs. Claudine Richard (CNRS) for advice on the use of the electron microprobe, to Mr. Jean Naud (Université Catholique de Louvain), for part of the X-ray powder-diffraction work, and to Mrs. Raymonde Gibert (Ecole Nationale Supérieure des Mines, Saint-Etienne) for the thermal records. Mr. Régis Piret (Université Catholique de Louvain) kindly communicated some of the XRD and EMP results used for this study. The authors are grateful to Drs. Mehmet Taner, Robert F. Martin, and an anonymous referee for their thorough reviews of an earlier draft.

\section{REFERENCES}

AgreLL, S.O. (1965): Polythermal metamorphism of limestone at Kilchoan, Ardnamurchan. Mineral. Mag. 34 (Tilley vol.), 1-15.

APPleman, D.E. \& Evans, H.T., JR. (1973): Indexing and leastsquares refinement of powder diffraction data. U.S. Geol. Surv., Comput. Contrib. 20 (NTIS Doc. PB-216).

Armbruster, T., Birrer, J., Libowitzky, E. \& Beran, A. (1998): Crystal chemistry of Ti-bearing andradites. Eur. J. Mineral. 10, 907-921.

BAUER, T. \& BAUR, W.H. (1998): Structural changes in the natural zeolite gismondine (GIS) induced by cation exchange with $\mathrm{Ag}, \mathrm{Cs}, \mathrm{Ba}, \mathrm{Li}, \mathrm{Na}, \mathrm{K}$ and Rb. Eur. J. Mineral. 10, 133-147.

BENOIT, P.H. (1987): Adaptation to microcomputer of the Appleman-Evans program for indexing and least-squares refinement of powder-diffraction data for unit-cell dimensions. Am. Mineral. 72, 1018-1019.

Bentor, I.K., Gross, S. \& Heller, L. (1963): Some unusual minerals from the "Mottled Zone" complex, Israel. Am. Mineral. 48, 924-930.

BuRnham, C.W. (1959): Contact metamorphism of magnesian limestones at Crestmore, California. Geol. Soc. Am., Bull. 70, 879-920.

Constantinescu, E., Ilinca, G. \& Ilinca, A. (1988): Contributions to the study of the Oraviţa - Ciclova skarn occurrence, southwestern Banat. D.S. Inst. Geol. Geofiz. 72-73/ 2, 27-45. 
Coombs, D.S., Alberti, A., Armbruster, T., Artioli, G., Colella, C., Galli, E., Grice, J.D., Liebau, F., Mandarino, J.A., Minato, H., Nickel, E.H., Passaglia, E., Peacor, D.R., Quartieri, S., Rinaldi, R., Ross, M., Sheppard, R.A., Tillmanns, E. \& Vezzalini, G. (1997): Recommended nomenclature for zeolite minerals: report of the Subcommittee on Zeolites of the International Mineralogical Association, Commission on New Minerals and Mineral Names. Can. Mineral. 35, 1571-1606.

Dickens, B. \& Bowen, J.S. (1971): Refinement of the crystal structure of the aragonite phase of $\mathrm{CaCO}_{3}$. J. Res. Nat. Bur. Standards, A. Phys. Chem. 75, 27-32.

Droop, G.T.R. (1987): A general equation for estimating $\mathrm{Fe}^{3+}$ concentrations in ferromagnesian silicates and oxides from microprobe analyses, using stoichiometric criteria. Mineral. Mag. 51, 431-435.

Eberhard, E., Hamid, S.A. \& RÖTtGer, B. (1981): Strukturverfeinerung und Polytipie von Xonotlit $\mathrm{Ca}_{6}\left[\mathrm{Si}_{6} \mathrm{O}_{17}\right](\mathrm{OH})_{2}$. Z. Kristallogr. 154, 271-272.

Fischer, K. \& KuZEL, H. (1958): Elementarzelle und Raumgruppe von Gismondin. Naturwiss. 45, 488.

Groat, L.A., Hawthorne, F.C. \& Ercit, T.S. (1992): The chemistry of vesuvianite. Can. Mineral. 30, 19-48.

HAMID, S.A. (1981): The crystal structure of the $11 \AA$ natural tobermorite $\mathrm{Ca}_{2.25}\left[\mathrm{Si}_{3} \mathrm{O}_{7.5}(\mathrm{OH})_{1.5}\right] \cdot 1 \mathrm{H}_{2} \mathrm{O}$. Z. Kristallogr. 154, 189-198.

Hamid Rahman, S. \& Beyrau, H. (1988): Die Bestimmung der Kristallstruktur von einem natürlichen 14 A-Tobermorit mit hilfe von Röntgen- und Elektronenbeugung. $Z$. Kristallogr. 182, 114-116.

HARKER, R.I. (1964): Dehydration series in the system $\mathrm{CaSiO}_{3}-$ $\mathrm{SiO}_{2}-\mathrm{H}_{2}$ O. J. Am. Ceram. Soc. 47, 521-529.

Henmi, C. \& KuSACHI, I. (1989): Monoclinic tobermorite from Fuka, Bitchu-cho, Okayama Prefecture, Japan. J. Mineral. Petrol. Econ. Geol. 84, 374-379 (in Japanese).

Kawahara, A. \& Henmi, K. (1977): Fukalite, a new calcium carbonate silicate hydrate mineral. Mineral. J. (Japan) 8, 374-381.

Istrate, G., Ştefan, A. \& Medeşan, A. (1978): Spurrite and tilleyite in the Cornet Hill, Apuseni Mountains, Romania. Rev. Roum. Géol., Géophys., Géogr., sér. Géol. 22, 143-153.

Kretz, R. (1983): Symbols for rock-forming minerals. Am. Mineral. 68, 277-279.

Kusachi, I., Henmi, C. \& Henmi, K. (1980): 10 Å tobermorite from Fuka, the town of Bitchu, Okayama Prefecture. Mineral. J. (Japan) 14, 314-322 (in Japanese).

Louisnathan, S.J. (1971): Refinement of the crystal structure of a natural gehlenite, $\mathrm{Ca}_{2} \mathrm{Al}(\mathrm{Al}, \mathrm{Si})_{2} \mathrm{O}_{7}$. Can. Mineral. 10, 822-837.
Mamedov, H.S. \& Belov, N.V. (1956): Crystal structure of the minerals of the wollastonite group. I. Structure of xonotlite. Zap. Vses. Mineral. Obshchest. 85, 13-38 (in Russ.).

MANDARINO, J.A. (1999): Fleischer's Glossary of Mineral Species. The Mineralogical Record Inc., Tucson, Arizona.

MCConNell, J.D.C. (1954): The hydrated calcium silicates riversideite, tobermorite and plombièrite. Mineral. Mag. 30, 293-305.

(1955): A chemical, optical and X-ray study of scawtite from Ballycraigy, Larne, N. Ireland. Am. Mineral. 40, 510-514.

MitsudA, T. \& TAYLOR, H.F.W. (1978): Normal and anomalous tobermorites. Mineral. Mag. 42, 229-235.

Murdoch, J. (1955): Scawtite from Crestmore, California. Am. Mineral. 40, 505-509.

Pascal, M.L., Fonteilles, M., Verkaeren, J., Piret, R. \& MARINCEA, S. (2001): Genetic conditions of the melilitebearing high-temperature skarns of the Apuseni Mountains, Carpathians, Romania. Can. Mineral. 39, 1405-1434.

Passaglia, E. \& RinAldi, R. (1984): Katoite, a new member of the $\mathrm{Ca}_{3} \mathrm{Al}_{2}\left(\mathrm{SiO}_{4}\right)_{3}-\mathrm{Ca}_{3} \mathrm{Al}_{2}(\mathrm{OH})_{12}$ series and a new nomenclature for the hydrogrossular group of minerals. Bull. Minéral. 107, 605-618.

PIRET, R. (1997): Minéralogie et géochimie des skarns de haute température des régions de Magureaua Vatei et de Cornet Hill (Monts Apuseni). M.Sc. thesis, Université Catholique de Louvain, Louvain-la-Neuve, Belgium.

Verkaeren, J. \& Marincea, Ş. (1997): Mineralogy and geochemistry of the high-temperature skarns of Cornet Hill and Magureaua Vatei (Apuseni Mountains). Discovery of scawtite and paraspurrite. Rom. J. Mineral. 78, Suppl. 1, 74-75.

\& PASCAL, M.-L. (1998): Paraspurrite, tilleyite and scawtite from the high temperature calcic skarns of the Cerboia (sic) Valley (Apuseni Mountains, western Carpathians, Romania). Paragenetic analysis of the skarns and geochemistry of their associated igneous rocks. Geol. Assoc. Can. - Mineral. Assoc. Can., Program Abstr. 23, A-147.

Pluth, J.J. \& Smith, J.V. (1973): The crystal structure of scawtite, $\mathrm{Ca}_{7}\left(\mathrm{Si}_{6} \mathrm{O}_{18}\right)\left(\mathrm{CO}_{3}\right) \cdot 2 \mathrm{H}_{2} \mathrm{O}$. Acta Crystallogr. B 29, 73-80.

Pouchou, J.-L. \& PichoIR, F. (1985): PAP $\phi(\rho z)$ procedure for improved quantitative microanalysis. In Microbeam Analysis (J.T. Armstrong ed.). San Francisco Press, San Francisco, California (104-106).

ReVerdatto, V.V. (1970): The Facies of Contact Metamorphism (V.S. Sobolev, ed.). Nedra, Moscow, Russia (in Russ.). 
Ross, M., Flohr, M.J.K. \& Ross, D.R. (1992): Crystalline solution series and order-disorder within the natrolite mineral group. Am. Mineral. 77, 685-703.

Sabine, P.A. \& Young, B.R. (1975): Metamorphic processes at high temperature and low pressure: the petrogenesis of the metasomatized and assimilated rocks of Carneal, Co. Antrim. Phil. Trans. R. Soc. London A280, 225-269.

Smith, J.V., Karle, I.L., Hauptman, H. \& Karle, J. (1960): The crystal structure of spurrite, $\mathrm{Ca}_{5}\left(\mathrm{SiO}_{4}\right)_{2} \mathrm{CO}_{3}$. II. Description of structure. Acta Crystallogr. 13, 454-458.

Ştefan, A., Istrate, G. \& MedeşAn, A. (1978): Gehlenite in calc-skarns from the Magureaua Vatei-Cerboaia (Apuseni Mountains - Romania). Rev. Roum. Géol., Géophys., Géogr., Sér. Géol. 22, 155-160.

Lazar, C., Berbeleac, I. \& Udubaşa, G. (1988): Evolution of the banatitic magmatism in the Apuseni Mts. and the associated metallogenesis. D. S. Inst. Geol. Geofiz. 72-73/2, 195-213.

TAYLOR, H.F.W. (1997): Cement Chemistry (second ed.). Thomas Telford Publishing, London, U.K.
TILLEY, C.E. (1929): On larnite (calcium orthosilicate, a new mineral) and its associated minerals from the limestone contact-zone of Scawt Hill, Co. Antrim. Mineral. Mag. 22, $77-86$.

(1938): On scawtite pseudomorphs after spurrite at Scawt Hill, Co. Antrim. Mineral. Mag. 35, 38-40.

VeZZALini, G. \& OBERTI, R. (1984): The crystal chemistry of gismondines: the non-existence of K-rich gismondines. Bull. Minéral. 107, 805-812.

von CottA, B. (1864): Erzlagerstätten im Banat und in Serbien. W. Braumüller Ed., Wien, Austria.

Yoshinaga, N. \& Aomine, S. (1962): Imogolite in some Ando soils. Soil Sci. Plant. Nutr. 8, 22-29.

Zhang, Li-Ming, Fu, Ping-Qiu, Yang, He-Xiong, Yu, KaIBeI \& ZHOU, ZHONG-YUAN (1992): Crystal structure of scawtite. Chin. Sci. Bull. 37, 930-934.

Received July 30, 2000, revised manuscript accepted July 7 , 2001. 